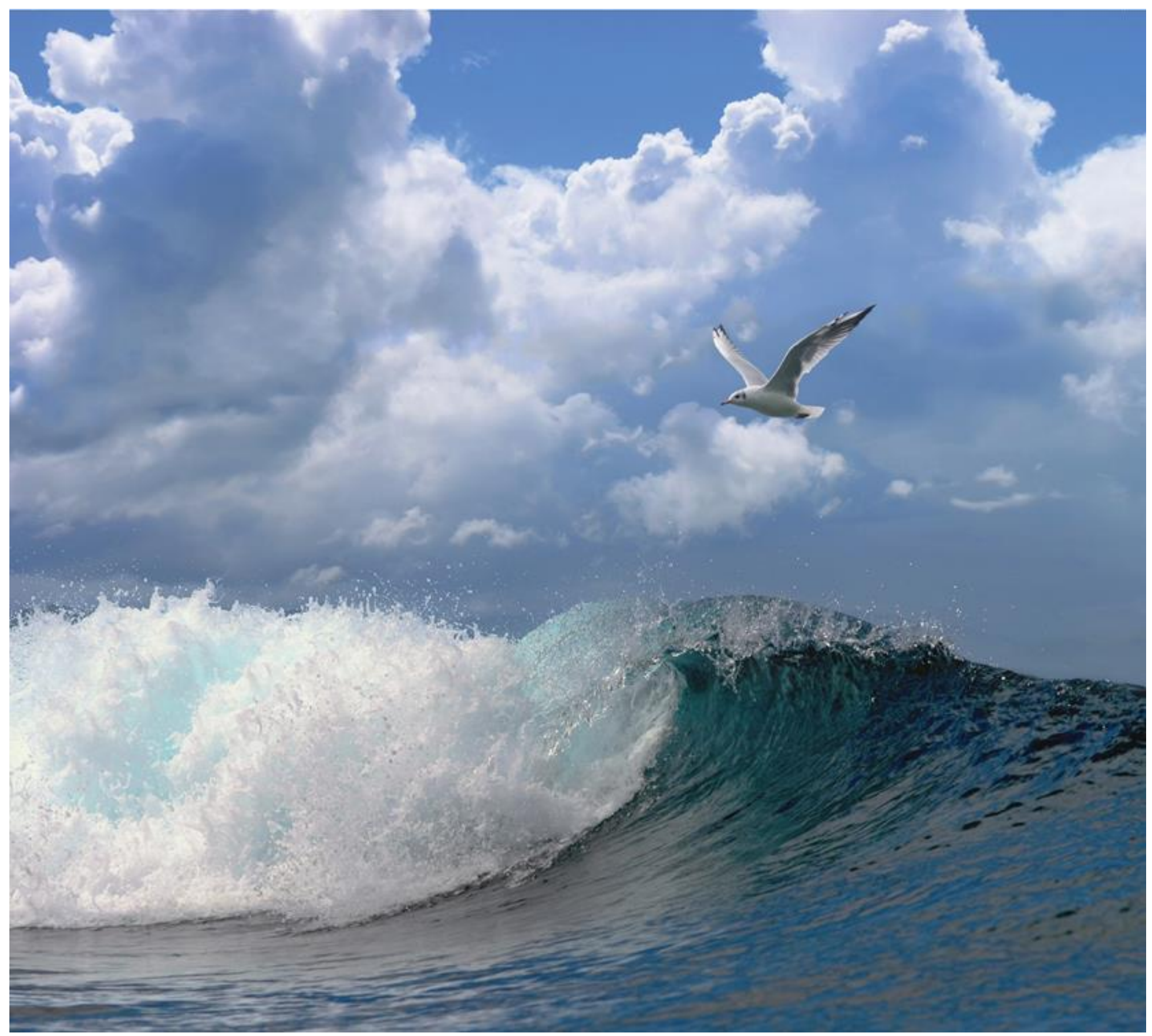

\title{
Condition and survival of discards in tickler chain beam trawl fisheries
}




\section{Condition and survival of discards in tickler chain beam trawl fisheries}

Authors: $\quad$ Edward Schram, Pieke Molenaar, Raoul Kleppe, Adriaan Rijnsdorp 
Keywords: Pulse beam trawl fisheries, tickler chain beam trawl, discards, fish condition, discards survival probability

Client: $\quad$ Ministerie van Landbouw, Natuur en Voedselkwaliteit Attn.: Dhr. Herman Snijders and Mw. Maddalena Visser Postbus 20401

2500 EK, Den Haag

This report can be downloaded for free from https://doi.org/10.18174/519613 Wageningen Marine Research provides no printed copies of reports

Wageningen Marine Research is ISO 9001:2015 certified.

\section{(C) Wageningen Marine Research}

Wageningen Marine Research, an institute Wageningen Marine Research accepts no liability for consequential damage, nor within the legal entity Stichting for damage resulting from applications of the results of work or other data Wageningen Research (a foundation under obtained from Wageningen Marine Research. Client indemnifies Wageningen Dutch private law) represented by Dr. Marine Research from claims of third parties in connection with this application. M.C.Th. Scholten, Managing Director All rights reserved. No part of this publication may be reproduced and / or

KvK nr. 09098104, published, photocopied or used in any other way without the written permission WMR BTW nr. NL 8113.83.696.B16.

Code BIC/SWIFT address: RABONL2U IBAN code: NL 73 RABO 0373599285 


\section{Contents}

$\begin{array}{lr}\text { Summary } & 4\end{array}$

$1 \quad$ Introduction $\quad 5$

$2 \quad$ Materials and Methods $\quad 7$

$\begin{array}{lll}2.1 & \text { Experiment } & 7\end{array}$

2.1.1 General set up $\quad 7$

2.1.2 Collection of test-fish 9

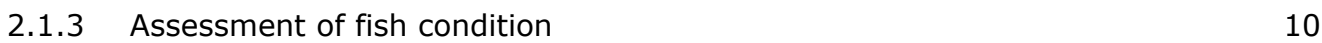

2.2 Data analysis $\quad 10$

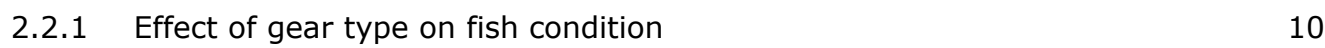

2.2.2 Prediction of discards survival in tickler chain beam trawling 12

$\begin{array}{llr}3 & \text { Results } & 13\end{array}$

3.1 Operational and environmental variables $\quad 13$

3.2 Direct mortality among discarded fish 13

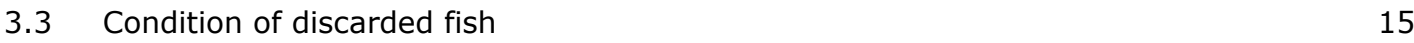

$\begin{array}{lll}3.3 .1 & \text { Vitality index scores } & 15\end{array}$

$\begin{array}{lll}3.3 .2 & \text { Damage scores } & 17\end{array}$

$\begin{array}{lll}\text { 3.3.3 Reflex impairment } & 17\end{array}$

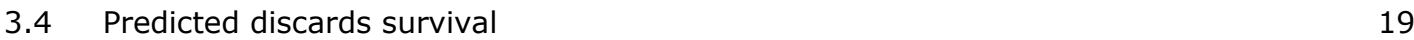

4 Discussion $r 2$

5 Conclusions $\quad 24$

$6 \quad$ Acknowledgements $\quad 25$

$\begin{array}{llr}7 & \text { References } & 26\end{array}$

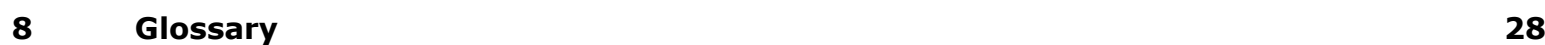

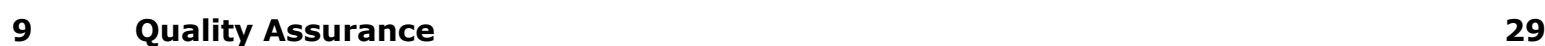

$\begin{array}{lr}\text { Justification } & \mathbf{3 0}\end{array}$ 


\section{Summary}

Dutch demersal fisheries in the North Sea is a mixed fishery that mainly targets Dover sole (Solea solea) with plaice (Pleuronectes platessa), turbot (Scophthalmus maximus), brill (Scophthalmus rhombus) and other species as valuable bycatches. The fleet currently uses two gear types: pulse beam trawls and conventional tickler chain beam trawls.

Pulse beam trawlers operate with a temporary exemption from the EU prohibition to use electric stimulation in fishing gears, of which the last exemptions will expire in June 2021. To assess the consequences of transitions between pulse and tickler chain beam trawling for discards mortality, knowledge on the discards survival probabilities as well as the amount of discards is required for both gear types. The objective of the current study was to estimate discards survival probabilities for undersized plaice, sole, turbot, brill and thornback ray discarded by tickler chain beam trawl fisheries using fish condition as a proxy for survival probability. To this end the condition and reflex impairment of undersized fish in the catches of tickler chain beam trawlers were assessed and compared to similar data collected from pulse trawl fisheries. For spotted ray we assessed fish condition in tickler chain beam trawling but could not estimate its discards survival probability because a relation between survival probability and fish condition is lacking for this species.

In this study direct mortality imposed by the tickler chain beam trawling ranged between 10 and $32 \%$ in flatfish species and was between 2-4 times higher than in pulse beam trawling. Direct mortality in ray species was lowest among the investigated species (2-8\%) and did not differ between the two gear types. Differences in direct mortality were reflected in the condition scores. Direct mortality of sole was higher in tickler chain beam trawling (17\%) than in pulse beam trawling ( $8 \%)$. Brill, turbot and plaice discarded by pulse beam trawling are in better condition than when discarded by tickler chain beam trawl fisheries. For sole no effect of gear type on fish condition could be detected. We consider the lower fish condition scores of brill, plaice and turbot from tickler chain beam trawling a direct reflection of the higher mechanical impact of this gear on the fish. For thornback ray and spotted ray no effect of gear type on fish condition could be detected.

The predicted survival of plaice, brill and turbot discards indicate that discards survival could indeed be lower in tickler chain beam trawl fisheries compared to pulse beam trawl fisheries. For sole and thornback ray discards we found no evidence for such difference between gear types. The discards survival probabilities for tickler chain beam trawling as presented in this study should be considered as predictions based on the currently best available information instead of definite values. Actual measurements of discards survival at sea are needed to confirm and quantify survival probabilities in tickler chain beam trawling. 


\section{Introduction}

Dutch demersal fisheries in the North Sea is a mixed fishery that mainly targets Dover sole (Solea solea) with plaice (Pleuronectes platessa), turbot (Scophthalmus maximus), brill (Scophthalmus rhombus) and other species as valuable bycatches. The fleet currently uses two gear types: pulse beam trawls and conventional tickler chain beam trawls. Conventional beam trawls are equipped with tickler chains to mechanically disturb flatfish from the seabed into the net. In pulse beam trawls the mechanical stimulation has been replaced by electrical stimulation which invokes a cramp response in fish which immobilise the fish above the seabed (Van Stralen, 2005; Soetaert et al., 2015), making them available to pass over the approaching footrope and into the trawl. Starting in 2009, a significant part of the Dutch demersal fishing fleet targeting sole made a transition to pulse beam trawling, mainly due to an increased catch efficiency for sole and a significantly lower fuel consumption as a result of reduced gear weight and towing speed (Van Marlen et al. 2014; Haasnoot et al., 2016; Turenhout et al., 2016). In addition, the transition to pulse beam trawling also resulted in a reduction of the bycatch of benthos and undersized fish (Van Marlen et al., 2014) and a reduction of seabed disturbance compared to tickler beam trawl fisheries (Depestele et al., 2016). Hence, a transition from mechanical stimulation to electrical stimulation in the sole fishery may mitigate the adverse ecological impacts and contribute to the ecological sustainability of the fishery. Pulse beam trawlers operate with a temporary exemption from the EU prohibition to use electric stimulation in fishing gears, of which the last exemptions will expire in June 2021.

To assess the consequences of transitions between pulse and tickler chain beam trawling for discards mortality, knowledge on the discards survival probabilities as well as the amount of discards is required for both gear types. Fish discarded by commercial fisheries are exposed to multiple stressors during capture, handling and release and the severity of these stressors is influenced by environmental conditions as well as characteristics of the fishery (Cook et al., 2019). Since mortality among discarded fish ultimately results from failure to recover from the stress response and impacts of stressors such as injuries (Cook et al, 2019), characteristics of the fisheries that exacerbate the severity of stressors are probably important for discards survival probability. Given the higher weight of the trawl, the higher towing speed and the use of tickler chains that chase fish from the seabed, we hypothesized that fish condition is poorer in tickler chain beam trawling than in pulse beam trawling, and that predicted discards survival is consequently lower in tickler chain beam trawling.

Survival of discarded fishes in pulse trawls has been recently studied by Van der Reijden et al. (2017) and Schram and Molenaar (2018). Combining the data of these two studies resulted in survival probability estimates (95\% confidence intervals in parenthesis) of $14 \%(12 \%-17 \%)$ for plaice and $26 \%$ (23\%-29\%) for sole (Schram et al., in prep). For the other species, discards survival probability estimates were 30\% (20-43\%) for turbot, 13\% (7-23\%) for brill, 53\% (40-65\%) for thornback ray and $44 \%$ for spotted ray (based on two trips only) (Schram and Molenaar, 2018). For tickler chain beam trawls discards survival probabilities of plaice and sole were estimated to be less than $10 \%$ (Van Beek et al., 1990). For beam trawl fishery with chain mats using $4 \mathrm{~m}$ wide gears, $48 \%$ of plaice and $14 \%$ of sole discards respectively survived $77 \mathrm{~h}$ and $91 \mathrm{~h}$ post capture. However, these monitoring periods were considered too short to represent true survival probability and subsequent model predictions of extended survival indeed resulted in lower survival probabilities (plaice: 0-24\%, sole 0$9 \%$ ) (Depestele et al., 2014). In the same study $72 \%$ of sampled Rajidae survived after $80 \mathrm{~h}$ post capture; a monitoring period known to be too short to obtain reliable discards survival data for thornback rays (Schram and Molenaar, 2018). An average survival of 50\% was found for plaice discards collected from $4 \mathrm{~m}$ beam trawls with chain mats when monitored up to fourteen days post capture (Uhlmann et al., 2016). According to these authors, this survival is restricted to the rather mild conditions for coastal vessels with relatively short hauls (60 $\mathrm{min}$ ) and low total catch weights (< $1 \mathrm{t}$ ). For plaice, sole and Rajidae discards survival estimates that are representative for the majority of the present day beam trawl fleet on the North sea, i.e. $12 \mathrm{~m}$ wide beam trawls with tickler chains and 
120 min hauls, seem lacking. For turbot and brill data on discards survival in tickler chain beam trawling seem unavailable.

The objective of the current study was to estimate discards survival probabilities in tickler chain beam trawling using fish condition as a proxy for survival probability. To this end the condition and reflex impairment of undersized plaice, sole, turbot, brill, spotted ray and thornback ray fish in the catches of tickler chain beam trawlers were assessed (Van der Reijden et al., 2017) and compared to similar data collected from pulse trawl fisheries (Schram and Molenaar, 2018). 


\section{Materials and Methods}

\section{$2.1 \quad$ Experiment}

\subsubsection{General set up}

We compared the condition of discarded fish between tickler chain and pulse beam trawl fisheries for undersized plaice (Pleuronectus platessa), sole (Solea solea), turbot (Scophthalmus maximus), brill (Scophthalmus rhombus), thornback ray (Raya clavata) and spotted ray (Raya montagui). Data on the condition of discards from pulse beam trawl fisheries were previously collected in our discards survival studies during nine trips with commercial pulse beam trawlers (Schram and Molenaar, 2018). Data on the condition of discards from tickler chain beam trawl fisheries were collected as part of the current study during three trips on two commercial trawlers.

All fishery operations were conducted in the Southern North Sea according to conventional, regular commercial practices. The trawlers were comparable in length (39-42m), with engine powers of 1125 $1471 \mathrm{~kW}$. Both pulse and tickler chain beam trawls were commercial gears with a $12 \mathrm{~m}$ width and a cod-end mesh size of $80 \mathrm{~mm}$. Pulse beam trawls used rubber discs as false ground rope in the gear, with a total weight between $80-140 \mathrm{~kg}$ and were towed at a 4.5-5 knot speed. Tickler chain beam trawls were towed at 5.8-6.2 knots and used chain ground ropes with a central section with rubber discs. Additional specifics are presented in Table 1 for the pulse beam trawlers and in Table 2 for the tickler chain beam trawlers. For each haul during a trip operational and environmental conditions were recorded (Table 3).

Table 1. Pulse beam trawl gear specifics

\begin{tabular}{|c|c|c|c|c|c|}
\hline & & \multicolumn{4}{|c|}{ Vessel } \\
\hline \multicolumn{2}{|l|}{ Specifics } & A & B & C & D \\
\hline \multirow[t]{5}{*}{ Electrodes } & Number & 25 & 22 & 24 & 26 \\
\hline & Type & HFK & HFK & HFK & HFK \\
\hline & Total length (m) & 6.7 & 7.5 & 7.2 & 7.4 \\
\hline & Distance between electrodes $(\mathrm{cm})$ & 42.5 & 40.0 & 42.5 & 41.5 \\
\hline & Length electrodes on seabed (m) & 3.2 & 3.0 & 3.2 & 4.75 \\
\hline \multirow[t]{4}{*}{ Conductor elements } & Number & 10 & 11 & 10 & 12 \\
\hline & Diameter $(\mathrm{mm})$ & 28 & 35 & 28 & 33 \\
\hline & Length (mm) & 130 & 130 & 130 & 134 \\
\hline & Distance between elements $(\mathrm{mm})$ & 210 & 220 & 210 & $200 \& 600$ \\
\hline \multirow[t]{5}{*}{ Pulse } & Power (kW/gear) & 5.2 & 6.0 & 5.3 & 7.3 \\
\hline & Width ( $\mu s)$ & 260 & 340 & 390 & 330 \\
\hline & Frequency $(\mathrm{Hz})$ & 80 & 60 & 45 & 60 \\
\hline & Peak voltage over electrode (V) & 60 & 60 & 60 & 60 \\
\hline & $\begin{array}{l}\text { Maximum exposure duration to pulse } \\
\text { field (s) }\end{array}$ & 1.3 & 1.2 & 1.3 & 1.7 \\
\hline
\end{tabular}


Table 2. Tickler chain beam trawl gear specifics

\begin{tabular}{|c|c|c|c|}
\hline & & \multicolumn{2}{|c|}{ Vessel } \\
\hline \multicolumn{2}{|l|}{ Specifics } & A & B \\
\hline Tickler chains & Number \& diameter (mm) & $8 \times 19$ & $\begin{array}{c}1 \times 25 \\
1 \times 23 \\
1 \times 22 \\
1 \times 21 \\
1 \times 20 \\
1 \times 19.25\end{array}$ \\
\hline Net ticklers & Number \& diameter $(\mathrm{mm})$ & $\begin{array}{l}7 \times 13 \\
5 \times 16\end{array}$ & $\begin{array}{c}1 \times 14 \\
1 \times 13 \\
1 \times 12 \\
1 \times 11 \\
1 \times 10 \\
1 \times 9 \\
1 \times 8 \\
1 \times 7.5 \\
1 \times 7 \\
1 \times 6.5 \\
1 \times 6 \\
1 \times 5 \\
1 \times 4.5 \\
1 \times 4 \\
\end{array}$ \\
\hline \multirow[t]{3}{*}{ Ground rope } & Length (m) & 36 & 37 \\
\hline & Diameter chain (mm) & 24 & 24 \\
\hline & $\begin{array}{l}\text { Length central rubber section } \\
\text { ground rope }(\mathrm{m})\end{array}$ & 6 & 7 \\
\hline
\end{tabular}

Table 3. Operational and environmental conditions and the range of their values recorded during sea trips.

\begin{tabular}{|l|c|c|l|}
\hline Abiotic variables & Unit & Level & \\
\hline Time in catch sorting process & min & Fish & Time difference between catch on deck and sampling \\
\hline Depth & $\mathrm{m}$ & Haul & Estimated using average reading of depth sounder during \\
\hline Seafloor & - & Haul & According to skipper's information and navigation equipment \\
\hline Wave height & $\mathrm{m}$ & Haul & Nearest measurement in database of the Dutch Ministry of \\
\hline Surface water temperature & ${ }^{\circ} \mathrm{C}$ & Haul & Measured in sea surface water from deck wash pump \\
\hline Air temperature & ${ }^{\circ} \mathrm{C}$ & Haul & Measured outside the vessel's bridge \\
\hline Wind speed & $\mathrm{Bft}$ & Haul & Measured by navigation equipment \\
\hline Total catch mass ${ }^{1}$ & $\mathrm{~kg}$ & Haul & Estimated by skipper \\
\hline Haul duration & $\mathrm{hr}$ & Haul & Recorded by skipper \\
\hline
\end{tabular}

1) Total mass of unsorted catch of both trawls. Test-fish in the trawl were exposed to half of this mass. 


\subsubsection{Collection of test-fish}

Sampling procedures were generally the same for gear types. Test-fish were collected during regular, semi-automatic catch-processing. In this process, catches are discharged from the cod-end into a hopper (one hopper for each of the two cod-ends). From the hoppers, the catches are discharged into a central pit from which the catch is transported by a conveyer belt onto a sorting belt. Marketable fish are manually collected from the sorting belt by the crew. At the end of the sorting belt, the remaining catch, including fish that are discarded, drops into a gutter that discharges back into the sea. All testfish were randomly collected from the end of the sorting belt just before discarding.

Within each trip, fish were collected from multiple hauls to account for potential variation in fishing conditions among hauls. To obtain representative samples from hauls and account for the potential effects of processing time on fish condition, fish were collected as much as possible in equal numbers at both the start and the end of the catch-sorting process of each haul. For all species except plaice in both fisheries and sole in pulse beam trawl fisheries, abundance per haul was low. Fish therefore had to be sampled according to their availability in subsequent hauls and this resulted in variable numbers of sampled hauls per species as well as variable numbers of fish sampled per haul.

Plaice abundancy in catches by both fisheries was sufficient for balanced sampling. For tickler chain beam trawling, we collected 20 test-fish randomly from each haul, 10 at the start and 10 at the end of the catch-sorting process. In the discards survival study in pulse beam trawl fisheries, treatments to improve discards survival had been installed in one to the two hoppers while the other hopper was operated conventionally. To enable collection of separate fish samples per hopper treatment from the sorting belt, catches from both hoppers were processed separately so that they appeared as two separate batches on the sorting belt. The processing sequence of the two hoppers was alternated between hauls to obtain an equal average catch-processing time across the collected test-fish. Each haul 10 test-fish were randomly collected per hopper treatment from the end of the sorting belt just before discarding, 5 at the start and 5 at the end of the catch-sorting process. In the current study we only used the data of plaice sampled from the conventionally operated hopper.

Sole was sufficiently abundant in the pulse trawler hauls to sample ca. 15 test-fish from two hauls per trip resulting in a total of 30 test-fish per sea trip. Sole was less abundant in the catches of the tickler chain beam trawl fisheries and consequently test-fish were collected according to availability in the hauls.

The total number of test-fish collected per species and trip and the number of sampled hauls per species for tickler chain beam trawl fisheries is presented in Table 4.

Table 4. Sea trips and the number of test-fish and the number of hauls (in parenthesis) from which they were collected per species.

\begin{tabular}{|c|c|c|c|c|c|c|c|c|c|c|}
\hline Trip & Gear type & Vessel & Year & Month & \# Plaice & \# Sole & \# Turbot & \# Brill & $\begin{array}{c}\text { \# Thornback } \\
\text { ray }\end{array}$ & $\begin{array}{c}\text { \# Spotted } \\
\text { ray }\end{array}$ \\
\hline 1 & Pulse & 1 & 2017 & May & $60(4)$ & $31(4)$ & $9(3)$ & $9(3)$ & $10(5)$ & - \\
\hline 2 & Pulse & 2 & 2017 & May & $60(6)$ & $30(3)$ & $11(5)$ & $12(5)$ & $11(4)$ & - \\
\hline 3 & Pulse & 3 & 2017 & June & $60(6)$ & $30(3)$ & $15(5)$ & $15(8)$ & $9(4)$ & - \\
\hline 4 & Pulse & 3 & 2017 & July & $59(6)$ & $30(3)$ & $8(3)$ & $9(3)$ & $9(3)$ & - \\
\hline 5 & Pulse & 1 & 2017 & Sept & $80(6)$ & $33(5)$ & $31(6)$ & $9(2)$ & $14(4)$ & - \\
\hline 6 & Pulse & 3 & 2017 & Oct & $60(6)$ & $30(2)$ & $12(4)$ & $9(3)$ & $14(7)$ & - \\
\hline 7 & Pulse & 2 & 2017 & Dec & $60(6)$ & $30(2)$ & $9(3)$ & $8(3)$ & $9(3)$ & - \\
\hline 8 & Pulse & 1 & 2018 & Jan & $60(6)$ & $30(2)$ & $9(3)$ & $10(7)$ & $10(5)$ & $14(6)$ \\
\hline 9 & Pulse & 2 & 2018 & Feb & $59(6)$ & $30(3)$ & $7(5)$ & $9(5)$ & $9(4)$ & $9(3)$ \\
\hline 10 & Tickler chains & 4 & 2018 & June & $140(7)$ & $60(5)$ & $30(4)$ & $5(3)$ & $14(6)$ & $4(3)$ \\
\hline 11 & Tickler chains & 4 & 2018 & June & $120(6)$ & $61(5)$ & $32(3)$ & $30(5)$ & $31(11)$ & $35(10)$ \\
\hline 12 & Tickler chains & 5 & 2018 & Nov & $120(6)$ & $28(7)$ & $15(3)$ & $6(4)$ & $2(2)$ & $23(4)$ \\
\hline Total & Pulse & & & & $558(52)$ & $274(27)$ & $111(37)$ & $90(39)$ & $99(39)$ & $23(9)$ \\
\hline Total & Tickler chains & & & & $380(19)$ & 149 (17) & $77(13)$ & $41(12)$ & $47(19)$ & $62(23)$ \\
\hline
\end{tabular}




\subsubsection{Assessment of fish condition}

Fish condition in both fisheries was assessed according a standardized protocol. After collection from the sorting belt, test-fish were temporarily stored in $105 \mathrm{~L}$ holding containers filled with seawater. The seawater in the holding containers was regularly renewed to maintain sufficient dissolved oxygen levels during storage. Upon completion of fish collection, fish were sequentially taken from the temporary holding containers for fish condition assessment and to measure total length ( $T L$ : in $\mathrm{cm}$ below). The condition of each individual fish was assessed by scoring vitality class, external damage and reflex impairment as described by Van der Reijden et al. (2017) and summarized in Table 5. For thornback and spotted ray the protocols for external damage and reflex impairment scores in flatfish by Van der Reijden et al. (2017) were adapted (Schram and Molenaar, 2018) (Table 5).

\subsection{Data analysis}

\subsubsection{Effect of gear type on fish condition}

Gear type treatment had two levels: pulse beam trawl and tickler chain beam trawl. For all test-fish $(\mathrm{N}=3818)$ fish condition, damages, reflex impairment and direct mortality were scored. Fish condition was expressed using a vitality index score with four levels $(A, B, C, D)$.

For fish condition $4 \times 2$ contingency tables were constructed separately for each species. The frequency distributions in these tables were analysed for significant treatment effects considering the two-sided $\mathrm{p}$-values for Fisher's Exact test.

To test the hypothesis that the probability of good fish condition $(A B)$ is higher in pulse beam trawling than tickler chain beam trawling, $2 \times 2$ contingency tables were constructed per species. To obtain two instead of four vitality classes as required for this analysis, vitality score indices $A$ and $B$ were combined in class $A B$ (good fish condition) and vitality score indices $C$ and $D$ were combined in class $C D$ (poor fish condition). The contingency tables were organized such that the first cell of the $2 \times 2$ tables contained the frequency of class $A B$ for pulse beam trawl fisheries. A right-sided $p$-value $<0.05$ then indicates that the probability of good fish condition $(A B)$ in pulse trawl fisheries exceeds the probability of good fish condition in beam trawl fisheries. The risks and their $95 \%$ confidence intervals of fish in good condition $(A B)$ in pulse beam trawling relative to tickler chain beam trawling were calculated (relative risks), separately for each species. These relative risks indicate how much more often fish in good condition ( $A B$ ) occurred in pulse beam trawling compared to tickler chain beam trawling. Relative risks were calculated as the quotient of the probability of fish in good condition ( $A B)$ in pulse and the probability of fish in good condition in tickler chain beam trawling.

Response variables damage score (present/absent), reflex impairment (impaired/not impaired) and direct mortality (dead/alive) all had two response levels. For each combination of treatment and response variable, $2 \times 2$ contingency tables where constructed. For all damage scores and reflex impairments as well as direct mortality among discards we hypothesized that frequencies are higher in tickler chain beam trawling than in pulse beam trawling. The organization of each table (which response $*$ treatment combination appeared in the first cell) was such that these hypotheses could be tested by considering Fisher's Exact test right-sided p-value. The risks and their 95\% confidence intervals of direct mortality in tickler chain beam trawling relative to pulse beam trawling were calculated, separately for each species. These relative risks indicate how much more often direct mortality occurred among discarded fish in tickler chain beam trawling compared to pulse beam trawling. Relative risks were calculated as the quotient of the probability of direct mortality in tickler chain and the probability of direct mortality in pulse beam trawling.

All statistical procedures were separately applied to the different species in this study. For all statistical procedures the PROC FREQ procedure in SAS 9.2 was used. 
Table 5. Description of criteria to score vitality status (after Van der Reijden et al. (2017)).

\begin{tabular}{|c|c|}
\hline \multicolumn{2}{|c|}{ Vitality index - All species } \\
\hline Class & Description \\
\hline A & Fish lively, no visible signs of loss of scale or mucus layer. \\
\hline B & $\begin{array}{l}\text { Fish less lively, minor lesions and some scales missing, mucus layer } \\
\text { affected up to } 20 \% \text { of skin surface area, some point haemorrhaging on the } \\
\text { blind side. }\end{array}$ \\
\hline C & $\begin{array}{l}\text { Fish lethargic, intermediate lesions and some patches without scales, } \\
\text { mucus layer affected up to } 50 \% \text { of skin surface area, several point } \\
\text { haemorrhaging on the blind side. }\end{array}$ \\
\hline D & $\begin{array}{l}\text { Fish lethargic or dead, clear head haemorrhaging, major lesions and } \\
\text { patches without scales, mucus layer affected for more than } 50 \% \text { of the skin } \\
\text { surface area, significant point haemorrhaging on the blind side. }\end{array}$ \\
\hline \multicolumn{2}{|c|}{$\begin{array}{l}\text { Damage scores - All species (Damages marked with * were not scored for thornback an spotted } \\
\text { rays) }\end{array}$} \\
\hline Damage & Description ( 1 = present; $0=$ absent $)$ \\
\hline Fin or wings & Fins are damaged or split (including tail fin). Wings in case of rays. \\
\hline$>50 \% *$ & $\begin{array}{l}\text { Damage to skin surface, scale or mucus layer at more than } 50 \% \text { of the } \\
\text { dorsal body surface. }\end{array}$ \\
\hline Head haemorrhages* & Presence of a haemorrhage in the head of the fish \\
\hline $\begin{array}{l}\text { Hypodermic } \\
\text { haemorrhages }\end{array}$ & Presence of a hypodermic haemorrhage \\
\hline Intestines & $\begin{array}{l}\text { Intestines are protruding or are visible through damaged body tissue of the } \\
\text { fish. }\end{array}$ \\
\hline Wound & Presence of a wound such that flesh is visible. \\
\hline \multicolumn{2}{|c|}{ Reflex impairment scores - Plaice, sole, turbot and brill } \\
\hline Reflex & $\begin{array}{l}\text { Description ( } 1 \text { = impaired; no (clear) response within } 5 \mathrm{~s} \text { of observation; } 0 \\
=\text { unimpaired; obvious response within } 5 \mathrm{~s} \text { ). }\end{array}$ \\
\hline Body flex & $\begin{array}{l}\text { Fish is held out of the water on the palm of the hand with its ventral side } \\
\text { up. Fish actively tries to move head and tail towards each other or wriggle } \\
\text { out of the hand. }\end{array}$ \\
\hline Righting & $\begin{array}{l}\text { Fish is held on the fingers of two hands with the dorsal side touching the } \\
\text { water surface. When released the fish actively rights itself under water. }\end{array}$ \\
\hline Evasion & $\begin{array}{l}\text { Fish is held underwater in an upright position by supporting its ventral side } \\
\text { with the fingers and its dorsal side with the thumbs. When the thumbs are } \\
\text { lifted the fish actively swims away. }\end{array}$ \\
\hline Stabilize & $\begin{array}{l}\text { Untouched fish tries to find a stable position flat on the bottom by rhythmic } \\
\text { and swift movement of the fins and/or body. }\end{array}$ \\
\hline Tail grab & $\begin{array}{l}\text { Fish is gently held by the tailfin between the thumb and index finger. Fish } \\
\text { actively struggles free and swims away. }\end{array}$ \\
\hline Head complex & $\begin{array}{l}\text { Fish moves its operculum or mouth during } 5 \mathrm{~s} \text { of observation while laying } \\
\text { undisturbed under water. }\end{array}$ \\
\hline \multicolumn{2}{|c|}{ Reflex impairment scores - Thornback ray and spotted ray } \\
\hline Reflex & $\begin{array}{l}\text { Description ( } 1 \text { = impaired; no (clear) response within } 5 \mathrm{~s} \text { of observation; } 0 \\
=\text { unimpaired; obvious response within } 5 \mathrm{~s} \text { ). }\end{array}$ \\
\hline Wings & $\begin{array}{l}\text { Ray is held out of the water, dorsal side up with one hand supporting the } \\
\text { body at the head of the ray and the other hand supporting the body at the } \\
\text { base of the tail. The ray actively flaps its pectoral fins (wings). }\end{array}$ \\
\hline Eye retraction & $\begin{array}{l}\text { While in the water the ray is gently tapped on the head just behind the } \\
\text { eyes with a blunt probe. The ray actively retracts its eyes. }\end{array}$ \\
\hline Stabilize & $\begin{array}{l}\text { While resting on the bottom, the ray is gently held by the tail. When the tail } \\
\text { is lifted, the observer notices more resistance than caused by the weight of } \\
\text { the ray; as if the ray sucks its body to the bottom of the tank. }\end{array}$ \\
\hline Tail grab & $\begin{array}{l}\text { While resting on the bottom the ray is gently held by the tail. When the tail } \\
\text { is gently pulled backwards, the ray struggles free and swims away. }\end{array}$ \\
\hline
\end{tabular}




\subsubsection{Prediction of discards survival in tickler chain beam trawling}

Discards survival probabilities in tickler chain beam trawling were predicted per species except spotted ray, taking into direct mortality as follows:

$$
\operatorname{Survival}(\%)=\frac{\left(N_{A} * \operatorname{Surv}_{A}+N_{B} * \operatorname{Surv}_{B}+N_{C} * \operatorname{Surv}_{C}+N_{D-\text { alive }} * \operatorname{Surv}_{D-\text { alive }}\right)}{\left(N_{A}+N_{B}+N_{C}+N_{D-\text { alive }}+N_{D-\text { dead }}\right)} * 100 \% \text { (eq. 1) }
$$

Where:

- $\quad \mathrm{N}_{A, B, C}$ are the counts per vitality index score $A, B$ and $C$;

- $\quad N_{D}$-alive is the count of fish per vitality index score $D$ that were alive upon sampling;

- $\quad N_{D-d e a d}$ is the count of fish per vitality index score D that were considered dead upon sampling;

- $\quad$ Surv $_{A, B, C}$, are the vitality index score specific discard survival probability estimates for scores A, B and $C$ as previously established for pulse beam trawling presented in Table 6 (Schram and Molenaar, 2018);

- $\quad$ SurVD-alive is the vitality index score specific discard survival probability estimate for fish that were alive upon sampling and scored vitality index D (Table 6).

Discards survival probability estimates for pulse beam trawling include direct mortality. For the discards survival predictions for tickler chain beam trawling this was accounted for by splitting the fish that scored vitality index $D$ into sub sets that were either alive ( $N_{D}$-alive) or considered dead ( $N_{D}$-dead) upon sampling. Note that fish that were considered dead upon sampling all scored vitality index D. We then split the survival probability for vitality index score D as established for pulse beam trawling into the same sub sets (Table 6). The resulting survival estimate for fish alive upon sampling and scoring vitality index $D$ (Surv $\mathrm{D}_{\text {-alive }}$ ) was used in eq. 1 . Note that the survival probability of fish that were dead upon sampling is zero. For spotted ray the number of observations was too low to determine survival probability estimates per vitality index class. Consequently, no survival probabilities could be calculated for this species in tickler chain beam trawl fisheries.

Table 6. Vitality index score specific estimates for discards survival probability as observed for pulse trawl fisheries (Schram and Molenaar, 2018.). For vitality index D the survival probability is also given for the sub sets of fish that were alive upon sampling and fish that were dead upon sampling. Note that fish that were considered dead upon sampling all scored vitality index $D$.

\begin{tabular}{|c|c|c|c|c|c|c|}
\hline $\begin{array}{l}\text { Vitality } \\
\text { index }\end{array}$ & Sub set & \multicolumn{5}{|c|}{ Discards survival probability estimates (\%) } \\
\hline & & Plaice & Sole & Turbot & Brill & Thornback ray \\
\hline A & n.a. & 57 & 74 & 42 & 44 & 84 \\
\hline B & n.a. & 27 & 30 & 31 & 27 & 67 \\
\hline C & n.a. & 4 & 9 & 8 & 8 & 42 \\
\hline D & n.a. & 3 & 3 & 0 & 2 & 9 \\
\hline D & SurvD-alive & 4.3 & 4.2 & 0 & 2.5 & 10.8 \\
\hline
\end{tabular}




\section{Results}

\subsection{Operational and environmental variables}

Values for the operational and environmental variables during data collection at sea are presented in Figure 1 for pulse and tickler chain beam trawling. The average time sampled fish spend in the catch sorting process before being sampled (panel A), fishing depth (panel D), wind speed (panel G) and wave height (panel $\mathrm{H}$ ) are similar for the two gear treatments. Most remarkably different operational variables are the higher fishing (towing) speed (panel B) for tickler chain beam trawling and the longer haul duration (panel C) for pulse beam trawling. The range of total catch mass (panel E) is wider for pulse beam trawling which is probably attributable to the higher number of trips and hauls. Absolute values for total catch masses may be inaccurate as data are estimates by the skippers and not measurements. However, the overall result that total catch masses are generally higher for tickler chain beam trawling is in line with our field observations. The range of the water temperature is much wider for pulse beam trawling which is attributable to the trips for pulse being conducted year-round while the tickler chain beam trawl trips were only conducted in June and November.

\subsection{Direct mortality among discarded fish}

The percentage of discards that were dead when sampled from the catch (direct mortality) ranged between $1-10 \%$ in pulse trawling and between $4-32 \%$ in tickler chain trawling (Table 7 ). The probability of direct mortality is higher in tickler chain beam trawling compared to pulse beam trawling for the four flat fish species (Fisher's exact test right-sided p-value $<0.05$, Table 7 ). For the two ray species no effect of gear type on direct mortality was detected (Fisher's exact test right-sided p-value $>0.05$, Table 7). In other words, direct mortality among discards of plaice, brill, turbot and sole is lower in pulse beam trawl fisheries than in tickler chain beam trawl fisheries, while the direct mortality of discarded thornback and spotted ray does not significantly differ between the two gear types.

Table 7. Total number of fish sampled per species and gear type, number of fish alive and dead upon sampling and direct mortality among discarded fish (\%). Fisher's exact test two-sided $p$-values $<0.05$ indicate different counts for the status (dead or alive) per gear type within species. Fisher's exact right-sided $p$-values $<0.05$ indicate per species that a higher direct mortality in the tickler chain beam trawl fisheries compared to pulse beam trawl fisheries.

\begin{tabular}{|c|c|c|c|c|c|c|}
\hline \multirow[t]{2}{*}{ Species } & \multirow[t]{2}{*}{$\begin{array}{l}\text { Gear } \\
\text { type }\end{array}$} & \multicolumn{2}{|c|}{$\begin{array}{l}\text { Status of fish upon } \\
\text { sampling }\end{array}$} & \multirow{2}{*}{$\begin{array}{c}\text { Total \# } \\
\text { fish } \\
\text { sampled }\end{array}$} & \multirow{2}{*}{$\begin{array}{c}\text { Direct } \\
\text { mortality } \\
(\%)\end{array}$} & \multirow{2}{*}{$\begin{array}{l}\text { Fisher's } \\
\text { exact test } \\
\text { right-sided } \\
\text { p-value }\end{array}$} \\
\hline & & \# alive & \# dead & & & \\
\hline Brill & $\begin{array}{l}\text { Ticklers } \\
\text { Pulse }\end{array}$ & $\begin{array}{l}28 \\
82\end{array}$ & $\begin{array}{c}13 \\
8\end{array}$ & $\begin{array}{l}41 \\
90\end{array}$ & $\begin{array}{c}32 \\
9 \\
\end{array}$ & 0.002 \\
\hline Plaice & $\begin{array}{l}\text { Ticklers } \\
\text { Pulse }\end{array}$ & $\begin{array}{l}286 \\
498 \\
\end{array}$ & $\begin{array}{l}94 \\
56\end{array}$ & $\begin{array}{l}380 \\
554\end{array}$ & $\begin{array}{l}25 \\
10 \\
\end{array}$ & $<0.001$ \\
\hline Turbot & $\begin{array}{l}\text { Ticklers } \\
\text { Pulse }\end{array}$ & $\begin{array}{c}69 \\
109 \\
\end{array}$ & $\begin{array}{l}8 \\
1 \\
\end{array}$ & $\begin{array}{c}77 \\
110 \\
\end{array}$ & $\begin{array}{c}10 \\
1 \\
\end{array}$ & 0.004 \\
\hline Sole & $\begin{array}{l}\text { Ticklers } \\
\text { Pulse }\end{array}$ & $\begin{array}{l}124 \\
252 \\
\end{array}$ & $\begin{array}{l}25 \\
22 \\
\end{array}$ & $\begin{array}{l}149 \\
274\end{array}$ & $\begin{array}{c}17 \\
8 \\
\end{array}$ & 0.006 \\
\hline Thornback ray & $\begin{array}{l}\text { Ticklers } \\
\text { Pulse }\end{array}$ & $\begin{array}{l}45 \\
92\end{array}$ & $\begin{array}{l}2 \\
2 \\
\end{array}$ & $\begin{array}{l}47 \\
94 \\
\end{array}$ & $\begin{array}{l}4 \\
2 \\
\end{array}$ & 0.41 \\
\hline Spotted ray & $\begin{array}{l}\text { Ticklers } \\
\text { Pulse }\end{array}$ & $\begin{array}{l}57 \\
21\end{array}$ & $\begin{array}{l}5 \\
1 \\
\end{array}$ & $\begin{array}{l}62 \\
22\end{array}$ & $\begin{array}{l}8 \\
5\end{array}$ & 0.5 \\
\hline
\end{tabular}


Relative risks were calculated to estimate how much more often directly mortality occurred in tickler chain compared to pulse beam trawling. Sole, plaice and brill had respectively 2.1, 2.4 and 3.6 times the risk of direct mortality in ticker chain compared to pulse beam trawling (Figure 2). Turbot had 11 times the risk of direct mortality in tickler chain compared to pulse beam trawling. This risk estimate is rather uncertain as shown by the wide $95 \%$ confidence interval (Figure 2 ). The two ray species have similar risks of direct mortality for the two gear types.

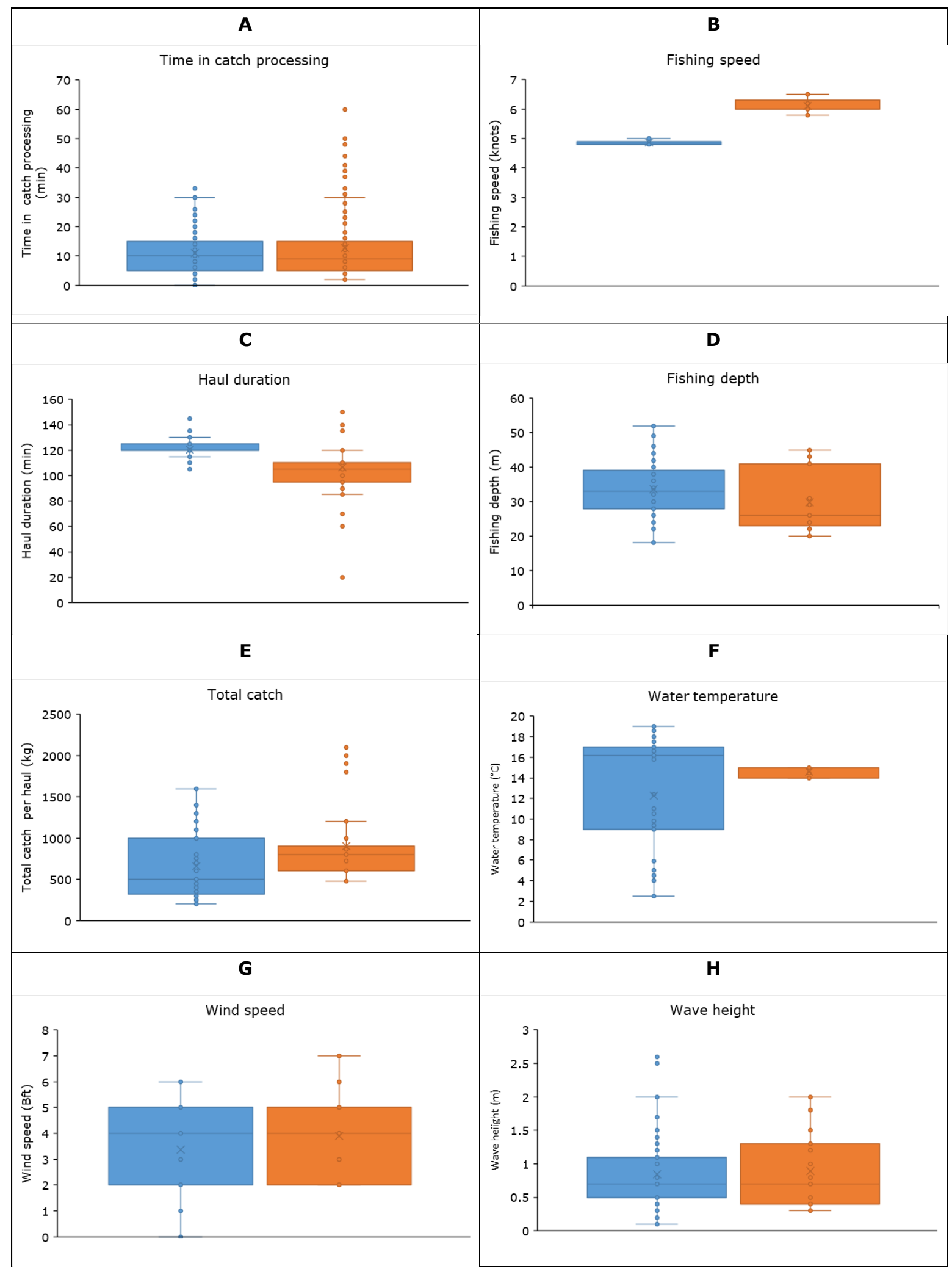

Figure 1. Operational and environmental conditions during data collection at sea for pulse beam trawling (blue) and tickler chain beam trawling (orange). 


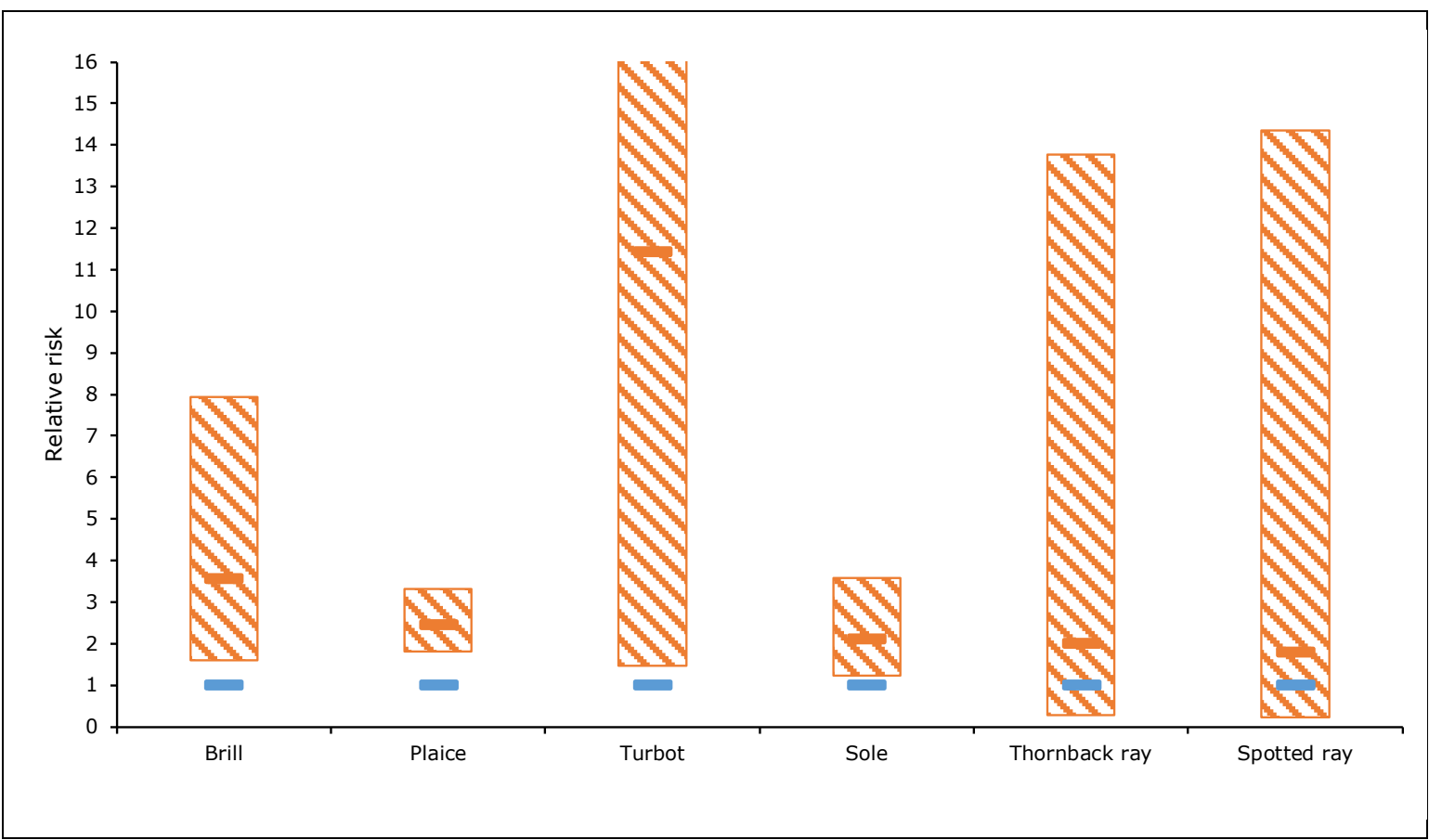

Figure 2. Relative risks (orange lines) and their 95\% confidence intervals (orange shaded boxes) per species of direct mortality in tickler chain beam trawl fisheries relative to pulse beam trawl fisheries (blue lines). The upper limit of the 95\% confidence interval for turbot is off scale at 89.5.

\subsection{Condition of discarded fish}

\subsubsection{Vitality index scores}

The frequency distributions over vitality index scores $A, B, C$ and $D$ for fish sampled by gear type is presented in Figure 3. The distributions differ for the two gear types (Fisher's exact test) for brill $(p=0.007)$, plaice $(p<0.001)$ and turbot $(p<0.001)$, indicating that the overall condition of these species was affected by the gear type. For sole $(p=0.82)$, thornback ray $(p=0.22)$ and spotted ray $(p=0.16)$ a significant effect of gear type on fish condition could not be detected.

To test the hypothesis that fish condition of discards is better in pulse than tickler chain beam trawling, 2x2 contingency tables ( combined vitality index * gear type) were constructed. Consistent with the differences detected for the frequency distributions for the vitality score indices $A$, $B, C$ and $D$ (Figure 3), the frequency distributions for the combined vitality score index * gear type are different (Figure 4$)$ with a higher probability of good condition $(A B)$ for brill $(p=0.001)$, plaice $(p<$ 0.001 ) and turbot $(p<0.001)$ discarded by pulse beam trawl fisheries compared to tickler chain beam trawl fisheries. For sole, thornback ray and spotted ray we found no evidence for gear type effects on condition of discards.

The probability of discards being in good condition in pulse relative to the probability in tickler chain beam trawling were calculated as relative risks (Figure 5). Especially the condition of brill discards appears to benefit from pulse beam trawling with a 4.6 times higher probability of being in good condition. Also the condition of plaice and turbot discards (relative risks both 2.1) discards appear to benefit from pulse beam trawling. For sole, thornback ray and spotted ray, the $95 \%$ confidence intervals of their respective relative risks overlap the relative risk of 1 for tickler chain beam trawling, indicating that the probability of discards being in good condition ( $A B$ ) does not differ between the two gear types. This is consistent with the results on the frequency distributions of the vitality score indices per gear type for these species. 


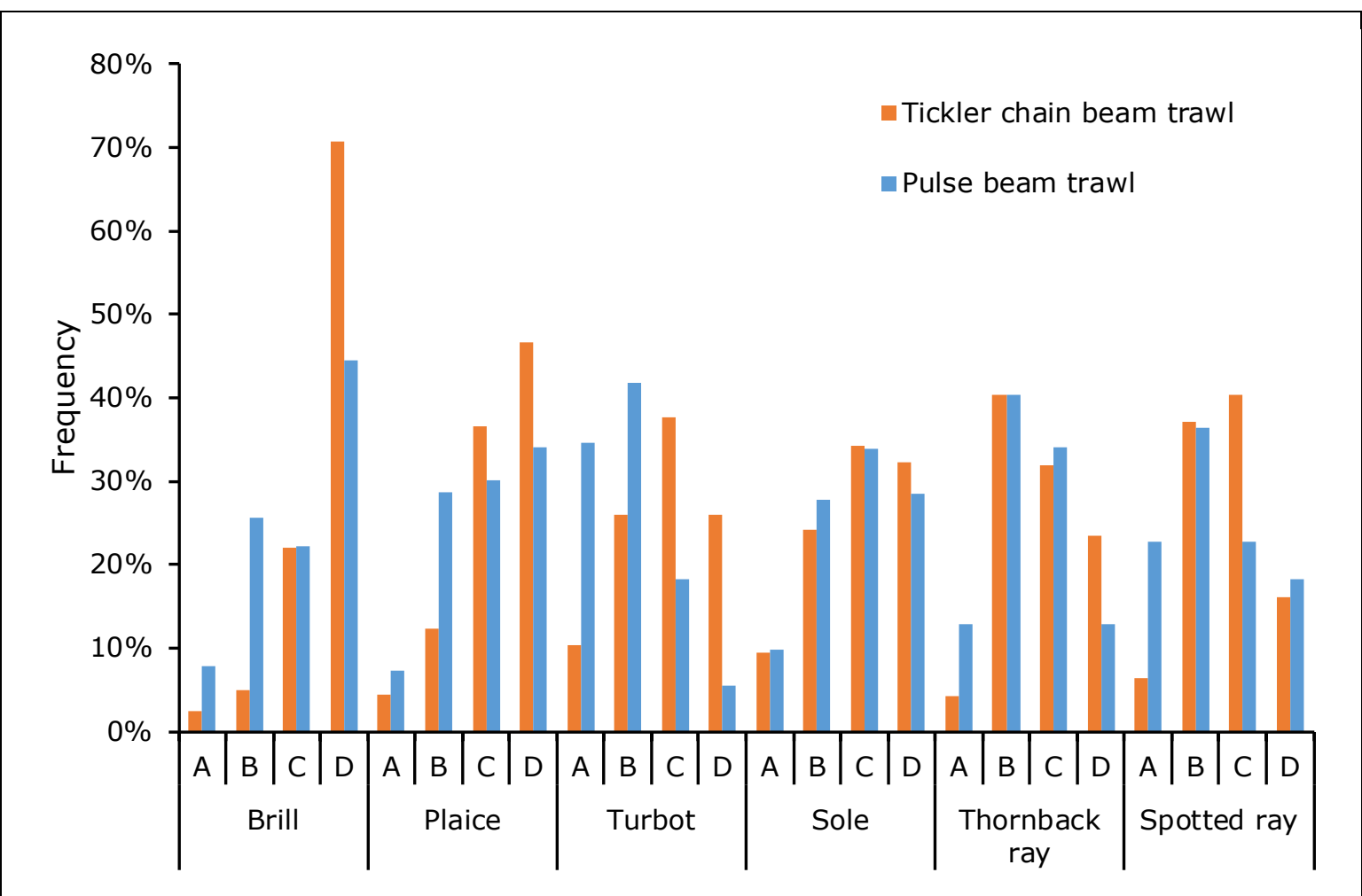

Figure 3. Frequency distributions of vitality index scores for fish sampled from pulse and tickler chain beam trawl fisheries.

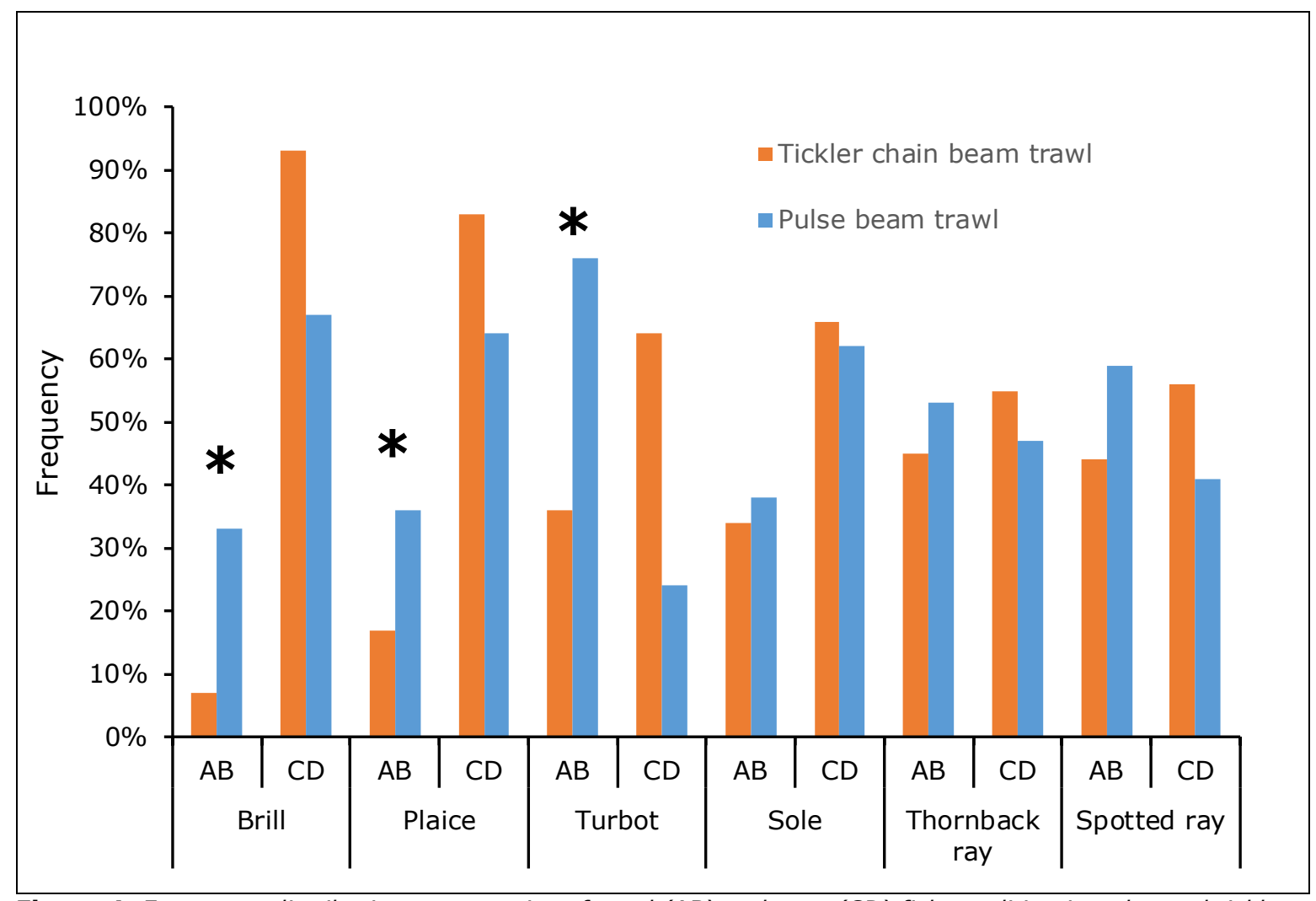

Figure 4. Frequency distributions per species of good (AB) and poor (CD) fish condition in pulse and tickler chain beam trawl fisheries. Asterixis mark a significantly higher proportion of fish in good condition in pulse beam trawling compared to tickler chain beam trawling (Fisher's exact test right-sided $p$-value $<0.05$ ). 


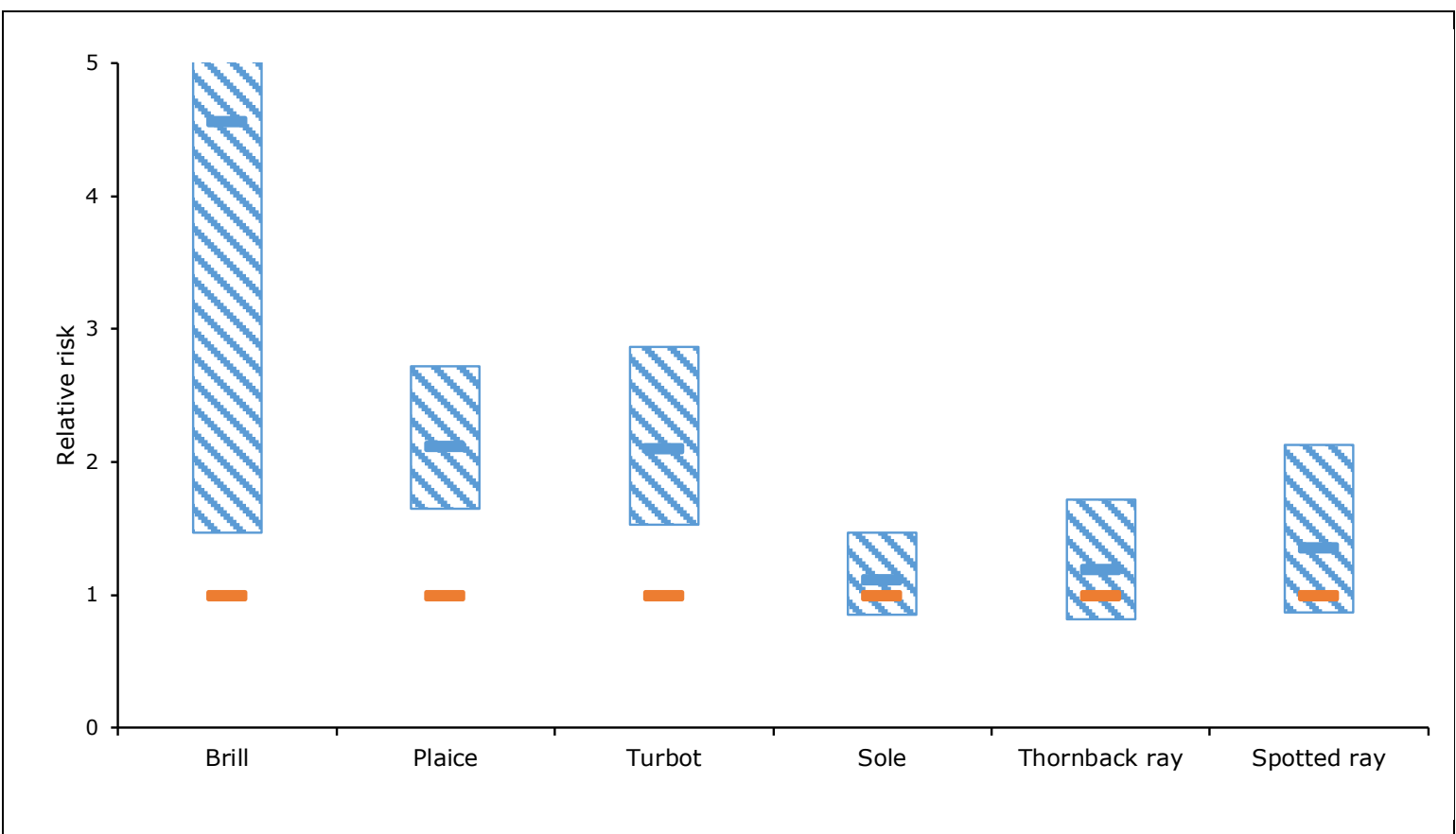

Figure 5. Relative risks (blue lines) and their 95\% confidence intervals (blue shaded boxes) per species of good fish condition $(A B)$ of discards in pulse beam trawl fisheries relative to tickler chain beam trawl fisheries (orange line). For brill the upper limit of the 95\% confidence interval is off scale at 14.1.

\subsubsection{Damage scores}

Each sampled fish was individually scored for the absence or presence of damaged fins or wings, damaged skin surface (scale loss), head haemorrhages, hypodermic haemorrhages, protruding intestines and wounds. The frequency distributions of the damage scorings are presented in Table 8. Scale loss and head haemorrhages were not determined (n.d.) for the two ray species.

In all cases where significant differences were detected in the presence of damages between the two gear types, the tickler chain beam trawl showed the highest prevalence.

Damaged fins were observed at a higher frequency among the fish sampled from tickler chain beam trawls in all species except sole. No difference in damaged wings between the two gear types was observed in both ray species. Skin surfaces damaged for more than $50 \%$ on the fish' dark side (scale loss) occurred more frequently among brill and plaice sampled from tickler chain beam trawls while for sole and turbot no gear effect could be detected. Head haemorrhages occurred more frequently in plaice and turbot sampled from tickler chain beam trawls while for brill and sole no gear effect could be detected. Hypodermic haemorrhages occurred more frequently in all species sampled from tickler chain beam trawls compared to pulse beam trawls except the ray species for which no effect of gear type was detected.

Protruding intestines and wounds are relatively rare with no differences between the gear types for all species, expect for the higher incidence of protruding intestines in plaice sampled from tickler chain beam trawls and a higher incidence of wounds in turbot sampled from pulse beam trawls.

\subsubsection{Reflex impairment}

Each individual fish was tested for the impairment of a set of reflexes or behavioural responses to stimuli. The frequency distribution over gear type of reflex impairment is presented per species in Table 9 for brill, plaice, turbot and sole and in Table 10 for thornback and spotted ray. Except for 'body flex' effects of gear type on reflex impairment could be detected for all reflexes and behavioural responses tested in at least two out of the four flatfish species (Fisher's exact test right-sided p-value $<0.05$, Table 9 ), indicating a reduced capacity to display behavioural responses to external stimuli among fish from tickler chain beam trawls. For the rays no effects of gear type on impairment could be detected for any of the reflexes and behavioural responses, except for a higher incidence of impairment of 'stabilize' in thornback ray from pulse trawl (Table 10). 
Table 8. Frequency of the presence of damages in brill, plaice, turbot, sole, thornback ray and spotted ray sampled from pulse beam trawl fisheries and tickler chain beam trawl fisheries. Fisher's Exact test two sided $p$-values $<0.05$ indicate significant differences within species in the occurrence of damages between the two gear types.

\begin{tabular}{|c|c|c|c|c|c|c|c|}
\hline \multirow[t]{2}{*}{ Species } & \multirow{2}{*}{$\begin{array}{l}\text { Gear } \\
\text { type }\end{array}$} & \multicolumn{6}{|c|}{ Frequency of damages (\%) } \\
\hline & & Fins/wings & Scale loss & $\begin{array}{l}\text { Head } \\
\text { haemorrhages }\end{array}$ & $\begin{array}{l}\text { Hypodermic } \\
\text { haemorrhages }\end{array}$ & $\begin{array}{l}\text { Protruding } \\
\text { intestines }\end{array}$ & Wounds \\
\hline Brill & \begin{tabular}{|l|} 
Pulse \\
Ticklers \\
p-value
\end{tabular} & $\begin{array}{c}69 \\
100 \\
<\mathbf{0 . 0 0 1} \\
\end{array}$ & $\begin{array}{c}59 \\
85 \\
\mathbf{0 . 0 0 3} \\
\end{array}$ & \begin{tabular}{|c|}
76 \\
88 \\
$\mathbf{0 . 1 6}$ \\
\end{tabular} & \begin{tabular}{|c|}
40 \\
68 \\
$\mathbf{0 . 0 0 4}$ \\
\end{tabular} & $\begin{array}{l}2 \\
0 \\
1 \\
\end{array}$ & $\begin{array}{l}4 \\
2 \\
1 \\
\end{array}$ \\
\hline Plaice & \begin{tabular}{|l} 
Pulse \\
Ticklers \\
p-value
\end{tabular} & $\begin{array}{c}60 \\
89 \\
<\mathbf{0 . 0 0 1} \\
\end{array}$ & $\begin{array}{c}60 \\
74 \\
<\mathbf{0 . 0 0 1} \\
\end{array}$ & $\begin{array}{c}63 \\
83 \\
<\mathbf{0 . 0 0 1} \\
\end{array}$ & $\begin{array}{c}47 \\
70 \\
<\mathbf{0 . 0 0 1} \\
\end{array}$ & $\begin{array}{c}1 \\
5 \\
0.001\end{array}$ & $\begin{array}{c}2 \\
1 \\
0.3 \\
\end{array}$ \\
\hline Turbot & \begin{tabular}{|l|} 
Pulse \\
Ticklers \\
p-value
\end{tabular} & $\begin{array}{c}31 \\
56 \\
\mathbf{0 . 0 0 1}\end{array}$ & $\begin{array}{c}8 \\
26 \\
0.002\end{array}$ & $\begin{array}{c}43 \\
70 \\
<\mathbf{0 . 0 0 1}\end{array}$ & $\begin{array}{c}28 \\
78 \\
<\mathbf{0 . 0 0 1}\end{array}$ & $\begin{array}{c}0 \\
0 \\
\text { n.a. }\end{array}$ & $\begin{array}{c}5 \\
0 \\
\mathbf{0 . 0 4}\end{array}$ \\
\hline Sole & \begin{tabular}{|l} 
Pulse \\
Ticklers \\
p-value
\end{tabular} & $\begin{array}{c}31 \\
34 \\
0.58\end{array}$ & $\begin{array}{c}66 \\
68 \\
0.75 \\
\end{array}$ & $\begin{array}{c}39 \\
38 \\
0.83\end{array}$ & $\begin{array}{c}40 \\
60 \\
<\mathbf{0 . 0 0 1}\end{array}$ & $\begin{array}{l}1 \\
1 \\
1\end{array}$ & $\begin{array}{c}5 \\
5 \\
0.82\end{array}$ \\
\hline $\begin{array}{l}\text { Thornback } \\
\text { ray }\end{array}$ & \begin{tabular}{|l|} 
Pulse \\
Ticklers \\
p-value
\end{tabular} & $\begin{array}{c}26 \\
36 \\
0.25 \\
\end{array}$ & $\begin{array}{l}\text { n.d. } \\
\text { n.d. } \\
\text { n.d. }\end{array}$ & $\begin{array}{l}\text { n.d. } \\
\text { n.d. } \\
\text { n.d. }\end{array}$ & $\begin{array}{c}90 \\
94 \\
0.75 \\
\end{array}$ & $\begin{array}{c}2 \\
6 \\
0.33 \\
\end{array}$ & $\begin{array}{l}34 \\
28 \\
0.7 \\
\end{array}$ \\
\hline $\begin{array}{l}\text { Spotted } \\
\text { ray }\end{array}$ & \begin{tabular}{|l} 
Pulse \\
Ticklers \\
p-value
\end{tabular} & $\begin{array}{c}14 \\
23 \\
0.54\end{array}$ & $\begin{array}{l}\text { n.d. } \\
\text { n.d. } \\
\text { n.d. }\end{array}$ & $\begin{array}{l}\text { n.d. } \\
\text { n.d. } \\
\text { n.d. }\end{array}$ & $\begin{array}{c}64 \\
85 \\
0.06\end{array}$ & $\begin{array}{c}0 \\
0 \\
\text { n.a. }\end{array}$ & $\begin{array}{c}14 \\
18 \\
0.75\end{array}$ \\
\hline
\end{tabular}

Table 9. Frequency of reflex impairment for brill, plaice, turbot and sole for pulse and tickler chain beam trawl fisheries. Fisher's Exact test right-sided p-values $<0.05$ indicate that reflexes and behavioural responses are more frequently impaired in tickler chain beam trawl fisheries.

\begin{tabular}{|c|c|c|c|c|c|c|c|}
\hline \multirow[t]{2}{*}{ Species } & \multirow{2}{*}{$\begin{array}{l}\text { Gear } \\
\text { type }\end{array}$} & \multicolumn{6}{|c|}{ Frequency of reflex or behavioural response impairment ( $\%)$} \\
\hline & & Body flex & Righting & Evasion & Stabilize & Tail grab & $\begin{array}{c}\text { Head } \\
\text { complex }\end{array}$ \\
\hline \multirow[t]{3}{*}{ Brill } & Pulse & 61 & 69 & 71 & 64 & 40 & 10 \\
\hline & Ticklers & 66 & 88 & 80 & 88 & 78 & 32 \\
\hline & p-value & 0.37 & 0.01 & 0.18 & 0.0041 & $<0.0001$ & 0.003 \\
\hline \multirow[t]{3}{*}{ Plaice } & Pulse & 79 & 29 & 52 & 48 & 20 & 10 \\
\hline & Ticklers & 75 & 57 & 61 & 55 & 46 & 26 \\
\hline & $p$-value & 0.94 & $<0.001$ & 0.002 & 0.019 & $<0.001$ & $<0.001$ \\
\hline \multirow[t]{3}{*}{ Turbot } & Pulse & 33 & 12 & 51 & 93 & 12 & 10 \\
\hline & Ticklers & 43 & 36 & 44 & 87 & 39 & 1 \\
\hline & p-value & 0.1 & $<0.001$ & 0.86 & 0.95 & $<0.001$ & 0.004 \\
\hline \multirow[t]{3}{*}{ Sole } & Pulse & 65 & 33 & 47 & 46 & 20 & 9 \\
\hline & Ticklers & 47 & 40 & 56 & 44 & 42 & 18 \\
\hline & p-value & 0.99 & 0.1 & 0.047 & 0.69 & $<0.001$ & 0.004 \\
\hline
\end{tabular}


Table 10. Frequency of reflex impairment for thornback ray and spotted ray for pulse and tickler chain beam trawl fisheries. Fisher's Exact test right-sided p-values $<0.05$ indicate that reflexes and behavioural responses are more frequently impaired in tickler chain beam trawl fisheries.

\begin{tabular}{|c|c|c|c|c|c|}
\hline \multirow[t]{2}{*}{ Species } & \multirow[t]{2}{*}{ Gear type } & \multicolumn{4}{|c|}{$\begin{array}{l}\text { Frequency of reflex or behavioural response } \\
\text { impairment }(\%)\end{array}$} \\
\hline & & Wings & $\begin{array}{l}\text { Eye } \\
\text { retraction }\end{array}$ & Stabilize & Tail grab \\
\hline \multirow[t]{3}{*}{ Thornback ray } & Pulse & 76 & 63 & 32 & 33 \\
\hline & Ticklers & 70 & 55 & 60 & 36 \\
\hline & p-value & 0.81 & 0.85 & 0.002 & 0.42 \\
\hline \multirow[t]{3}{*}{ Spotted ray } & Pulse & 91 & 59 & 55 & 36 \\
\hline & Ticklers & 66 & 50 & 68 & 39 \\
\hline & p-value & 0.99 & 0.84 & 0.2 & 0.53 \\
\hline
\end{tabular}

\subsection{Predicted discards survival}

Discards survival probabilities in tickler chain beam trawl fisheries were predicted from the frequency distributions over vitality index scores A, B, C and D in combination with previously established species specific discard survival probability estimates per vitality index score (Schram and Molenaar, 2018). The predicted discard survival probabilities in tickler chain beam trawl fisheries lie below the lower limits of the $95 \%$ confidence intervals of the survival probabilities established for pulse beam trawl fisheries in plaice, brill and turbot (Figure 6). For sole discards survival appears more or less equal in both fisheries (Figure 6). For thornback ray the predicted discards survival for tickler chain beam trawling is lower than the measured values for pulse beam trawling but still within the $95 \%$ confidence interval for pulse beam trawling (Figure 6).

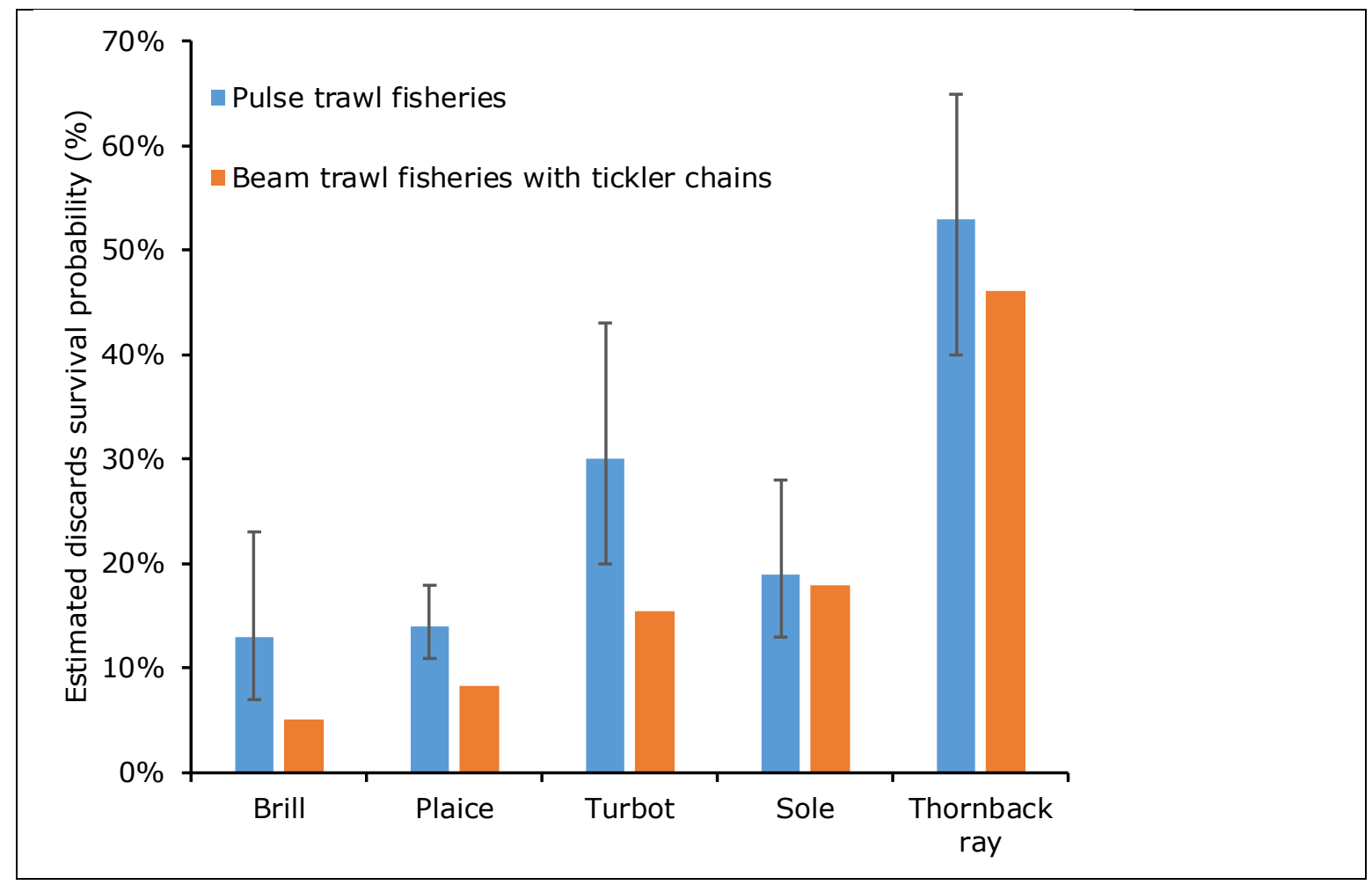

Figure 6. Discards survival probabilities per species for tickler chain (orange bars) and pulse beam trawl (blue bars) fisheries (copied from Schram and Molenaar (2018), error bars represent the 95\% confidence intervals for the survival probability estimates). 


\section{Discussion}

In this study we assessed the condition of flatfish and rays that are discarded by tickler chain beam trawl fisheries and compared our findings to previously measured fish condition in pulse beam trawl fisheries. We showed that the direct mortality imposed by the tickler chain beam trawling ranged between 10 and $32 \%$ in flatfish species and was between 2-4 times higher than in pulse beam trawling. Direct mortality in ray species was lowest among the investigated species (2-8\%) and did not differ between the two gear types. The difference in direct mortality was reflected in the condition scores. Brill, turbot and plaice discarded by pulse beam trawling are in better condition than when discarded by tickler chain beam trawl fisheries. For sole, thornback ray and spotted ray no effect of gear type on fish condition could be detected. The predicted survival of plaice, brill and turbot discards indicate that discards survival could be lower in tickler chain beam trawl fisheries compared to pulse beam trawl fisheries. For sole and thornback ray discards we found no evidence for such difference between gear types.

Fish discarded by commercial fisheries are exposed to multiple stressors during capture, handling and release and their severity is influenced by environmental conditions as well as characteristics of the fishery (Cook et al., 2019). Common stressors that may (lethally) damage fish caught by commercial fisheries include hypoxia, injury, exhaustion, barotrauma and predation. These stressors are described in detail by Cook et al. (2019). Next to mechanical impacts, pulse trawls impose electrical impacts on fish, what should be considered as a potential additional stressor. Response to stimuli after electrical stimulation has not been studied in fish (ICES, 2018) and our assessment of reflex impairment may to some extent reflect pulse exposure. Externally visible injuries however have not been observed in small-spotted catshark (Scyliorhinus canicula) (De Haan et al., 2009; Desender et al., 2017), Dover sole (Solea solea) (Soetaert et al., 2016) and common dab (Limanda limanda) (De Haan, 2015) following electrical stimulation in the laboratory for a range of pulse parameters. We therefore exclude electrical stimulation by the pulse trawl as important cause for the observed gear effects on fish condition and consequently attribute them to differences in mechanical impacts.

Neither the present study nor our previous studies attempted to establish causes of discards mortality. Although we do not rule out that exhaustion and sub lethal oxygen deficiencies sustained by the fish during capture and on deck catch processing contributed to reflex impairment and direct mortality in part of the tested fish, we consider internal and external injuries the most probable and important causes for reflex impairment and discard mortality. Interactions between fish and fishing gear always result to some degree of internal or external injury of fish (Davis, 2002). The type of injuries and their severity depend on the characteristics of the fisheries and the conditions at sea. Injuries such as loss of mucus layers, scale loss and skin damage result from fish contacting the gear, other fish, biota or debris in the catch and abrasion by sand (Cook et al., 2019). Crowding of fish in trawls typically results in bruising, crushing and constriction injuries as fish are pushed against other biota and debris or against or partially trough the cod-end mesh (Veldhuizen et al., 2018). Whether injuries are directly or eventually lethal depends on their nature, severity and ability of the fish to recover. Injuries can also lead to delayed mortality through secondary infections (Miller et al., 2014).

Injuries were observed in nearly all fish sampled in the current as well as in our previous studies (Van der Reijden et al., 2017; Schram and Molenaar, 2018) and it is clear that both tickler chain and pulse trawls have mechanical, injury causing impacts on the fish. However, characteristics of tickler chain beam trawling probably exacerbate the severity of mechanical impacts compared to pulse trawling. First of all, fish risk collisions with the heavy tickler chains and foot rope. The footrope of the tickler chain beam trawl consists of a thick chain with only a section of small rubber discs in the middle while the pulse trawl footrope is constructed completely of rubber discs. Gear parts unique to the pulse trawl, such as conductors, have lower weights than tickler chains, which makes it is reasonable to assume that severe injuries are less frequent. In a tickler chain beam trawl, fish probably have a higher risk of injury causing collisions because it catches more debris and rough surfaced benthic 
organisms than a pulse trawl (Van Marlen et al., 2014) and is towed at a higher speed (6-7 knots versus 5 knots in pulse trawling). At higher towing speeds fish will move quicker towards the cod end. Since haul duration is largely comparable for the two gear types, fish then spend more time in the cod end of a tickler chain beam trawl where they are vulnerable to injuries from contacts with the cod-end netting, other fish, biota and debris. These impacts will be further exacerbated by the more turbulent, higher energy environment in the cod end due to the higher towing speed. In addition, the higher towing speed combined with the deeper sediment penetration in tickler chain trawls probably causes more severe abrasion by sand (Depestele et al., 2016).

Jointly taken, it is reasonable to assume that the mechanical impacts on fish are more severe in tickler chain beam trawling compared to pulse beam trawling. We therefore consider the higher incidence of injuries and reflex impairment that we observed in brill, plaice and turbot from tickler chain beam trawling and the consequentially lower fish condition scores a direct reflection of the higher mechanical impact of this gear on the fish. The higher direct mortality we observed for all species except the rays seems to confirm the higher mechanical impact of the tickler chain trawl.

Conditions at sea were not identical for the pulse and tickler chain beam trawl trips and this may to some extent have contributed to the differences in fish conditions we observed for the two gear types. In pulse trawl fisheries, higher water temperatures have been shown to have a negative effect on plaice and a positive effect on turbot discards survival probabilities (Van der Reijden et al., 2017; Schram and Molenaar, 2018). Our observations for tickler chain beam trawling are restricted to relatively high temperatures $\left(12-17^{\circ} \mathrm{C}\right)$. Assuming that temperature effects on discards survival probability reflected in our fish condition assessments, our predicted discards survival probabilities are possibly a slight underestimation for plaice and a slight overestimation for turbot. Fish condition or discards survival assessments covering the complete annual temperature range would be required to confirm this. For other species no temperature effects on discards survival probability have been detected and we therefore expect our discards survival predictions to be unaffected by the restricted temperature range in the current study. Although there may be some effects of the conditions at sea, we consider the differences in fish conditions we observed for the two gear types to be largely attributable to differences in the characteristics of the fisheries.

In pulse beam trawling discards survival probabilities strongly depend on the condition in which undersized fish are discarded. This effect of fish condition on discards survival is generic across all species tested (Schram and Molenaar, 2018). Survival probability estimates range for example from $57 \%$ for plaice in good condition (vitality index score A) to as low as $3 \%$ for plaice in poor condition (vitality index score D) in pulse beam trawling. We used species and vitality index specific survival probability estimates for pulse beam trawl fisheries (Schram and Molenaar, 2018) in combination with the frequencies of vitality index scores established in the present study to predict the discards survival for tickler chain beam trawling. To this end, we assumed that the relation between vitality index score and survival probability is interchangeable between the two fishing gears: fish in comparable condition caught by either gears, score the same vitality index and have the same survival probability. Semiquantitative indices of fish condition have indeed been demonstrated to be good predictors for fish survival (Morfin et al., 2017; Uhlman et al., 2016) but as far as we know cross checks for interchangeability between gear types have not been made. Our main concern is that our fish condition assessment may not entirely reflect to what extend fish are exhausted while we suspect that this could differ between fish from the two gears. Our fish condition assessment detects complete exhaustion through reflex impairment and this will be reflected in the vitality index score. More subtle differences in exhaustion are reflected in the vitality index score when exhaustion renders this fish less lively. However, we cannot entirely exclude that we overestimated fish condition in exhausted fish and subsequently overestimated their survival probability. Exhaustion is probably more prominent among fish from tickler chain trawls due to the higher towing speed. In case exhaustion is important as an (indirect) cause of (delayed) discards mortality, we cannot exclude a slight overestimation of discards survival probability for the fish sampled from the tickler chain beams trawls.

Given the already observed differences in fish condition between the two gear types, it is not surprising that for all species tested the predicted discards survival probabilities are lower for tickler chain beam trawling. Differences between the two gear types in fish condition and the underlying 
damage and reflex impairment scores were most pronounced for brill, plaice and turbot. Although frequently observed in fish from both gear types, split fins, scale loss, head haemorrhages and hypodermic haemorrhages occurred in all but one case significantly more often in brill, plaice and turbot from tickler chain beam trawling. Reflex impairments generally also occurred more frequent among plaice, brill and turbot from tickler chain beam trawling. All this resulted in a significantly higher risk of poor fish condition for these species in tickler chain beam trawling. The difference in discards survival is consequently the largest for these species. Because of the indicative nature of the predicted discards survival for tickler chain beam trawling, statistical comparison of discards survival between the two gear types was not pursued. However, for plaice, brill and turbot the predicted discards survival for tickler chain beam trawling lie outside the $95 \%$ confidence intervals of the survival probability estimates for pulse trawl fisheries. For now, we therefore conclude that discards survival of undersized plaice, brill and turbot is most probably lower in tickler chain beam trawling than in pulse beam trawling. Direct measurements of discards survival in tickler chain beam trawl fisheries (with $12 \mathrm{~m}$ wide gears) are needed to corroborate this preliminary conclusion and to quantify the actual survival probabilities per species.

Apparently thornback ray is, at least compared to other species, relatively resistant to the impacts of the catching process, as reflected by the relatively high survival probability in pulse trawl fisheries (Schram and Molenaar, 2018). Their discards survival probability is also least related to their condition compared to other species. This may explain why the larger mechanical impact of tickler chain beam trawling does not seem to exacerbate the impact of the fisheries on thornback ray as reflected by the absence of gear effects on direct mortality, fish condition and underlying damage and reflex impairment scores. On the other hand, the frequency distributions over the vitality index scores seem to indicate poorer condition of thornback and spotted ray from tickler chain trawls and we do not rule out that a too low number of observations prevented us from detecting significant effects. Thornback ray discards survival probability as predicted for tickler chain beam trawling is very similar to the survival probability established for pulse beam trawling. Although the survival predicted for tickler chain trawling is slightly lower, it lies within the (lower) range of the $95 \%$ confidence interval of the measured discards survival for pulse beam trawling. In line with the above reasoning we therefore conclude for now that discards survival thornback ray does not differ between the two gears. However, we do not rule out that a larger sample size would reveal a lower thornback ray discards survival probability for tickler chain beam trawling compared to pulse trawls.

The number of observations on spotted ray in the discards survival study in pulse trawling was too low to establish fish condition specific discards survival estimates for this species. We consequently could not predict discards survival for tickler chain beam trawling for spotted ray.

Discards survival of plaice and sole has been estimated to be lower than 10\% (Van Beek et al., 1990). Our current findings are in line with this previous work for plaice but, surprisingly, not sole, for which we have no explanation other than that the husbandry conditions in the study by Van Beek et al. (1990), that we nowadays would consider suboptimal, may have caused additional mortality. We observed that many soles in the catches of both tickler chain and pulse beam trawling ended up as meshed fish. The meshing itself as well as the increased exposure to mechanical impacts during hauling and discharging the nets of meshed fish probably has a significant negative impact on the condition of the meshed fish. Indeed the discards survival of meshed sole is lower than for not meshed soles from the same catches (Van Marlen et al., 2016). Although we did not determine numbers of meshed sole relative to the total catch, the similar cod-end mesh size used in both gears makes it likely that the proportions of meshed sole were quite similar in tickler chain and pulse beam trawling. For sole we only detected a higher incidence of hypodermic haemorraghes while for half of the tested reflexes a higher frequency of impairment was detected in tickler chain beam trawling. No gear effect was detected on vitality index scores of sole. The lack of difference in fish condition between the two gear types for sole, i.e. no gear effect on vitality index scores was detected, may be very well explained by the impact of meshing overruling any other differences in the impacts of the gears on fish condition.

To compare total discard mortality between tickler chain and pulse beam trawling, we not only have to consider discards survival probabilities but also the total amount of discards produced per fishery. A detailed assessment of the amount of discards is ongoing but it has already been established that in 
general tickler chain beam trawling produces more discards than pulse beam trawling (Van Marlen et al., 2014). Combined with the findings of the current study regarding discards survival probabilities it seems reasonable to assume that total discards mortality is higher in tickler chain beam trawling than in pulse beam trawling. Direct measurements of discards survival in tickler chain beam trawl fisheries (with $12 \mathrm{~m}$ wide gears) are needed to corroborate this preliminary conclusion and to quantify the actual survival probabilities per species. 


\section{Conclusions}

Based on the current study we conclude the following:

- Direct mortality among discarded plaice, brill, turbot and sole is lower in pulse beam trawl fisheries than in tickler chain beam trawl fisheries;

- $\quad$ Direct mortality among discarded thornback and spotted ray does not differ between pulse and tickler chain beam trawl fisheries;

- Condition of plaice, brill and turbot discards is affected by gear type with the best fish condition observed for pulse beam trawling;

- Condition of sole discards was not affected by gear type, probably because the effect of meshing overruled the gear effect;

- Condition of thornback and spotted rays discards was not affected by gear type, although the data seem to suggest a better fish condition for rays from pulse beam trawling. We do not rule out that a too low sample size prevented the detection of significant gear effects;

- For plaice, brill and turbot, discards survival probabilities as predicted for tickler chain beam trawling are lower than discards survival probabilities measured in pulse beam trawling;

- $\quad$ For thornback ray the discard survival probability as predicted for tickler chain beam trawling seems comparable to the discards survival probability measured in pulse beam trawling;

The discards survival probabilities for tickler chain beam trawling as presented in this study should be considered as predictions based on the currently best available information instead of definite values. Actual measurements of discards survival at sea are needed to confirm and quantify survival probabilities in tickler chain beam trawling. 


\section{Acknowledgements}

This work was carried out as part of the project Impact Assessment Pulse Trawl Fisheries funded by the Dutch Ministry for Agriculture, Nature conservation and Food safety (contract no. 1300021172). This work would not have been possible without the contributions of the skippers, owners and crews of the participating pulse and beam trawlers. We thank AT-KB for their contributions to the field work. 


\section{$7 \quad$ References}

Cook, K.V., Reid, A.J., Patterson, D.A., Robinson, K.A., Chapman, J.M., Hinch, S.G., Cooke, S.J. 2019. A synthesis to understand responses to capture stressors among fish discarded from commercial fisheries and options for mitigating their severity. Fish and Fisheries 20, p 25-43.

Davis, M.W. 2002. Key principles for understanding fish bycatch discard mortality. Can. J. Fish. Aquat Sci. 59, 1834-1843.

Depestele, J., Desender, M., Benoit, H.P., Polet, H., Vincx, M. 2014. Short-term survival of discarded target fish and non-target invertebrate species in the eurocutter beam trawl fishery of the Southern North sea. Fisheries Research 154: 82-92.

Depestele, J., Ivanović, A., Degrendele, K., Esmaeili, M., Polet, H., Roche, M., Summerbell, K., et al. 2016. Measuring and assessing the physical impact of beam trawling. ICES Journal of Marine Science: Journal du Conseil, 73: i15-i26.

De Haan, D., van Marlen, B., Velzenboer, I., van der Heul, J. and van der Vis, H. 2009. The effect of pulse stimulation on biota - Research in relation to ICES advice - Effects on dogfish. ICES Document C105/09.

De Haan, D., Haenen, O., Chen, C., Hofman, H., van Es, Y., Burggraaf, D. and Blom, E. 2015. Pulse trawl fishing: The effects on dab (Limanda limanda). IMARES C171/14.

Desender, M. Kaijura, S., Ampe, B., Dumoulin, L., Polet, H., Chiers, K. and A. Decostere. 2017. Pulse trawling: Evaluating its impact on prey detection by small-spotted catshark (Scyliorhinus canicula). Journal of Experimental Marine Biology and Ecology 486: 336-343.

Haasnoot, T., Kraan, M., and Bush, S. R. 2016. Fishing gear transitions: lessons from the Dutch flatfish pulse trawl. ICES Journal of Marine Science: Journal du Conseil, 73: 1235-1243.

ICES. 2018. Report of the Working Group on Electric Trawling (WGELECTRA). 17-19 April 2018. IJmuiden, The Netherlands. ICES Document ICES CM 2018/EOSG: 10.

Morfin, M., Kopp, D., Benoît, H. P., Méhault, S., Randall, P., Foster, R., and Catchpole, T. 2017. Survival of European plaice discarded from coastal otter trawl fisheries in the English Channel. Journal of Environmental Management, 204: 404-412.

Morfin, M., Kopp, D., Benoît, H. P., and Méhault, S. 2019. Comparative assessment of two proxies of fish discard survival. Ecological Indicators, 98: 310-316.

Schram, E., Molenaar, P. 2018. Discards survival probabilities of flatfish and rays in North Sea pulsetrawl fisheries. Wageningen Marine Research Report C037/17.

Soetaert, M., Decostere, A., Polet, H., Verschueren, B., and Chiers, K. 2015. Electrotrawling: a promising alternative fishing technique warranting further exploration. Fish and Fisheries 16(1): 104-124.

Soetaert, M., Decostere, A., Verschueren, B., Saunders, J., Van Caelenberge, A., Puvanendran, V., Mortensen, A., Duchateau, L., Polet, H. and Chiers, K. 2016. Side-effects of electrotrawling: Exploring the safe operating space for Dover sole (Solea solea L.) and Antlantic cod (Gadus morhua L.). Fisheries Research. 177: 95-103.

Turenhout, M.N.J., B.W. Zaalmink, W.J. Strietman, K.G. Hamon. 2016. Pulse fisheries in the Netherlands; Economic and spatial impact study. Wageningen, Wageningen Economic Research, Report 2016- 104.

UhImann, S. S., Theunynck, R., Ampe, B., Desender, M., Soetaert, M., \& Depestele, J. 2016. Injury, reflex impairment, and survival of beam-trawled flatfish. ICES Journal of Marine Science, 73(4), 1244-1254.

Van Beek, E.A., Van Leeuwen, P.I., Rijnsdorp, A.D. 1990. On the survival of plaice and sole discards in the otter-trawl and beam-trawl fisheries in the North sea. Netherlands Journal of Sea Research 26 (1): 151-160.

Van der Reijden, K. J., Molenaar, P., Chen, C., Uhlmann, S.S., Goudswaard, P.C. Van Marlen, B. 2017. Survival of undersized plaice (Pleuronectes platessa), sole (Solea solea), and dab (Limanda limanda) in North Sea pulse-trawl fisheries. ICES Journal of Marine Science 74(6), 1672-1680. 
Van Marlen, B., Wiegerinck, J. A. M., van Os-Koomen, E., and van Barneveld, E. 2014. Catch comparison of flatfish pulse trawls and a tickler chain beam trawl. Fisheries Research, 151: 5769.

Van Stralen, M.R. 2005. De Pulskor, Samenvatting van het onderzoek naar de ontwikkeling van een alternatief vistuig voor de vangst van platvis gebaseerd op het gebruik van elektrische stimuli. MarinX-rapport 2005.26.

Van Marlen, B., Molenaar, P., Van der Reijden, K.J., Goudswaard, P.C., Bol, R.A., Glorius, S.T., Theunynck, R., Uhlmann, S.S. 2016. Overleving van discard platvis - Vaststellen en verhogen. IMARES rapport C180/15, IMARES Wageningen UR.

Veldhuizen, L.J.L., Berentsen, P.B.M., De Boer, I.J.M., Van de Vis, J.W., Bokkers, E.A.M. 2018. Fish welfare in capture fisheries: A review of injuries and mortality. Fisheries Research 204, p. 41-48. 


\section{Glossary}

Discards: all biota (e.g. fish, benthic organisms) and abiotic materials (e.g. stones, debris) in the catch that are not retained and landed but returned (discarded) to the sea. Discarded fish include nontarget species, species with no market value, target and non-target species below minimum landing sizes and over quota target and non-target species.

Discards survival probability (\%): the probability (\%) that fish survives on the long-term when first captured and then returned to sea (discarded).

Direct mortality (\%): fish that are dead when sampled from the catch expressed as a percentage of the total number of sampled fish. Direct discards mortality is used specifically in case of sampling of discards from the catch.

Relative risk: the risk for an event to happen in group 1 relative to the risk for the same event to happen in group 2 . 


\section{Quality Assurance}

Wageningen Marine Research utilises an ISO 9001:2015 certified quality management system. This certificate is valid until 15 December 2021. The organisation has been certified since 27 February 2001. The certification was issued by DNV GL.

Furthermore, the chemical laboratory at IJmuiden has EN-ISO/IEC 17025:2017 accreditation for test laboratories with number L097. This accreditation is valid until $1^{\text {th }}$ of April 2021 and was first issued on 27 March 1997. Accreditation was granted by the Council for Accreditation. The chemical laboratory at IJmuiden has thus demonstrated its ability to provide valid results according a technically competent manner and to work according to the ISO 17025 standard. The scope (L097) of de accredited analytical methods can be found at the website of the Council for Accreditation (www.rva.nl).

On the basis of this accreditation, the quality characteristic $Q$ is awarded to the results of those components which are incorporated in the scope, provided they comply with all quality requirements. The quality characteristic $Q$ is stated in the tables with the results. If, the quality characteristic $Q$ is not mentioned, the reason why is explained.

The quality of the test methods is ensured in various ways. The accuracy of the analysis is regularly assessed by participation in inter-laboratory performance studies including those organized by QUASIMEME. If no inter-laboratory study is available, a second-level control is performed. In addition, a first-level control is performed for each series of measurements.

In addition to the line controls the following general quality controls are carried out:

- Blank research.

- Recovery.

- Internal standard

- Injection standard.

- Sensitivity.

The above controls are described in Wageningen Marine Research working instruction ISW 2.10.2.105. If desired, information regarding the performance characteristics of the analytical methods is available at the chemical laboratory at IJmuiden.

If the quality cannot be guaranteed, appropriate measures are taken. 


\section{Justification}

Report C034/20

Project Number: 4311400010

The scientific quality of this report has been peer reviewed by a colleague scientist and a member of the Management Team of Wageningen Marine Research
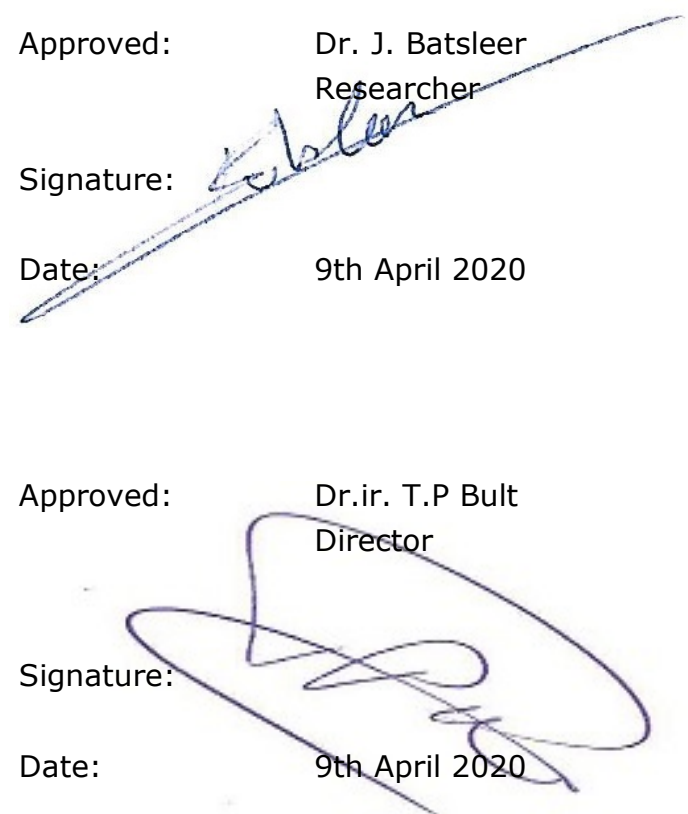
Wageningen Marine Research

$\mathrm{T}+31(0) 317480900$

E: marine-research@wur.nl

www.wur.eu/marine-research

Visitors' address

- Ankerpark 27, 1781 AG Den Helder

- Korringaweg 7, 4401 NT Yerseke

- Haringkade 1, 1976 CP IJmuiden
With knowledge, independent scientific research and advice, Wageningen Marine Research substantially contributes to more sustainable and more careful management, use and protection of natural riches in marine, coastal and freshwater areas.

Wageningen Marine Research is part of Wageningen University \& Research. Wageningen University \& Research is the collaboration between Wageningen University and the Wageningen Research Foundation and its mission is: 'To explore the potential for improving the quality of life' 